Discussion Paper No. 04-69

\title{
Determination of Potential Growth Using Panel Techniques
}

Marcus Kappler

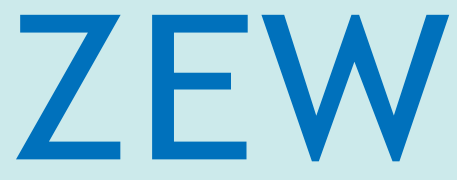

Zentrum für Europäische Wirtschaftsforschung $\mathrm{GmbH}$

Centre for European

Economic Research 
Discussion Paper No. 04-69

\title{
Determination of Potential Growth Using Panel Techniques
}

\author{
Marcus Kappler
}

Download this ZEW Discussion Paper from our ftp server:

\section{ftp://ftp.zew.de/pub/zew-docs/dp/dp0469.pdf}

Die Discussion Papers dienen einer möglichst schnellen Verbreitung von neueren Forschungsarbeiten des ZEW. Die Beiträge liegen in alleiniger Verantwortung der Autoren und stellen nicht notwendigerweise die Meinung des ZEW dar.

Discussion Papers are intended to make results of ZEW research promptly available to other economists in order to encourage discussion and suggestions for revisions. The authors are solely responsible for the contents which do not necessarily represent the opinion of the ZEW. 


\section{Non-Technical Summary}

The aim of this paper is to construct indicators of potential growth of GDP per capita for a range of industrial countries. The paper starts with a review of findings and considerations of the theoretical and empirical growth literature in order to give motivation for the empirical analysis. After this, the empirical model and econometric approach is demonstrated. Finally, estimation results are presented.

The econometric specification is derived from an extended neoclassical growth model allowing for a non-diminishing returns to scale production function, which is a standard approach in empirical growth research. For estimation, a panel data technique that is suited for integrated annual macroeconomic panel data sets is employed. It allows to estimate longrun relationships between GDP per capita and its determinants of the underlying cross-section of 12 industrial countries. Furthermore, this approach reconciles theoretical considerations concerning common and country-specific growth factors with the econometric setup.

Furthermore, empirical results of the underlying data for the time period from 1971 to 2000 are presented and interpreted. The data set covers various subject areas like fiscal policy, monetary policy, labour markets etc. and is described in detail in the appendix. Issues presented involve results of individual and panel unit root tests and panel cointegration tests as well as estimation results of panel error correction models. An overall empirical model is presented for the underlying cross-section of 12 countries that serves as a starting point for the calculation of the indicators of potential growth. This model contains the following variables (sign of impact on growth of GDP per capita in parentheses): investment in physical capital $(+)$, human capital $(+)$, government consumption $(-)$, terms of trade (-), non-cyclical unemployment rate $(-)$, standard deviation of inflation (-) and population growth (-).

Basically, the indicators of potential growth are the values of the fitted panel error correction model excluding short-term dynamics in order to eliminate business cycle effects. Since this specification focuses on the common growth factors of the underlying cross-section, for few countries (Belgium Japan, the Netherlands and the United States) predicted growth is lower than actual on average due to neglected country-specific determinants.

Finally, further possibilities to refine and extend the empirical approach are discussed. 


\title{
Determination of Potential Growth Using Panel Techniques
}

\author{
Marcus Kappler* \\ ZEW Mannheim \\ November 2004
}

\section{Abstract}

The aim of this paper is to construct an indicator of potential growth for developed countries using the insights of the theoretical and empirical growth literature. The Pooled Mean Group Estimator of Pesaran, Shin and Smith (1999) that employs a panel data technique is used. This estimator is suited for integrated annual macroeconomic panel data sets to estimate long-run relationships between GDP per capita and its determinants of the underlying cross-section of 12 industrial countries. Since this long-run relationship describes a sort of structural relationship, one can use the fitted model to calculate an indicator of potential growth. The first part of the paper reviews the existing growth literature with a special focus on industrial countries in order to motivate for the used variables in the econometric analysis. The next part explains the concept of panel unit roots and panel cointegration and introduces the underlying empirical approach. Next, empirical results are presented and discussed. Then, the calculation of the potential growth indicator is demonstrated. The last part of this paper concludes.

JEL-Classification: C32, O47, O57

Keywords: Economic growth, Panel data, unit root, cointegration

* Centre for European Economic Research (ZEW); P.O. Box 103443, D68034 Mannheim, Germany, Phone: +49/621/1235-157, Fax:

+49/621/1235-223, E-mail: kappler@zew.de 


\section{Introduction}

There is a large body of theoretical and empirical research on economic growth since explaining cross-country growth differentials is one of the most focused questions of economics. Especially the weak growth rates of the big EU-countries during the second part of the nineties have revived public interest on this topic. The aim of this paper is not to introduce a new set of potentially growth enhancing or growth impeding variables. Instead, the existing evidence and suggestions are used and combined in a new way to calculate indicators of potential growth to evaluate the driving forces of a range of industrial countries. Moreover, this paper employs an econometric approach that has been fruitful in recent empirical research. This attempt exploits the most information out of the available data and takes the time-series properties of these data into account. Furthermore, this approach reconciles theoretical considerations concerning parameter homogeneity and heterogeneity with the econometric setup. The econometric specification is derived from an augmented neoclassical growth model allowing for a nondiminishing returns to scale production function, which is a standard approach in empirical research (e.g. Mankiw, Romer and Weil, 1992, Islam, 1995, Barro, 1997). The econometric setup used in this paper goes back to Bassanini, Scarpetta and Hemmings (2001) who focus on the role of policies and institutions for growth of OECD countries.

The next section reviews findings and considerations of the theoretical and empirical growth literature in order to give motivation for the used variables in the empirical part of this paper.

\section{The proximate sources of growth}

The current understanding of economic growth still dates back to the neoclassical growth model of Solow (1956), although it has undergone changes in interpretation particularly in the light of endogenous growth theories.

\subsection{Physical capital}

The neoclassical model considers a production function with physical capital as the only reproducible input into the production process. The critical assumption of this model is that returns to scale to physical capital are diminishing. Therefore, investment in capital influences the level of aggregated output rather than the growth rate. Hence, in the long-run the growth rate of the economy is a function of the exogenous rate of population growth, the exogenous rate of technological change 
and the natural rate of capital depreciation. Even though the neoclassical model does not explain growth sustaining determinants based on economic decisions, at least it points to the most important factor: technological change.

Endogenous growth models support a broader view of capital and relax the assumption of diminishing returns to capital. The models of endogenous technological change for example incorporate knowledge as additional input to production. On the firm-level, the utilisation of knowledge in the production process still features diminishing returns to scale but generates economy-wide externalities through spill-over effects. ${ }^{1}$ Externalities also apply to physical capital if technological innovation is embodied in new capital and improves the economy-wide adoption of new technologies. ${ }^{2}$ For empirical applications, the accumulation of physical capital remains one of the key variables. It is usually measured as the investment share of GDP and will also be included in the empirical model of this paper.

\subsection{Human capital}

Another way to introduce externalities into growth models with a broad view of capital is to consider the role of human capital. Since the work of Mankiw, Romer and Weil (1992) it is a standard approach of empirical growth models to include a measure of human capital stock or a measure of its accumulation together with physical capital. This usually improves the fit of empirical models and is in line with theories emphasising the importance of education and training for growth. ${ }^{3}$

Whether the stock of human capital or its rate of accumulation matters for economic growth recently has gained attention and mainly depends on the theoretical approach. The Lucas (1988) model clearly stresses the importance of the accumulation of human capital while models of endogenous technological progress usually account for the stock of human capital. The empirical results obtained by Teles (2004) indicate that the Lucas (1988) model satisfactorily explains the growth rate of "rich" countries. Against the background of these findings the empirical part of this paper (see section 5) also uses a measure of human capital investment rather than a measure of the human capital stock since the attention is on growth determinants of "rich" industrial countries. Due to

\footnotetext{
${ }^{1}$ See Romer (1986), Grossman and Helpman (1991) or for models of endogenous technological change. A formal discussion of these type of endogenous growth models can be found in Durlauf and Quah (1999).

${ }^{2}$ E.g. De Long and Summers (1991) point to the importance of investment in equipment as a source of externalities

${ }^{3}$ A classical reference for a model of human capital is Lucas (1988)
} 
data limitations the focus of the human capital variable will be on schooling rather than training. Therefore, just one dimension of the much broader concept of human capital will be considered.

The just characterised determinants of growth make up the basic model of the empirical section. Therefore, it is straightforward to denote the following variables as wider sources of growth although one can not draw a line in the strict sense.

\section{The wider sources of economic growth}

\subsection{Research and development}

Theories of endogenous technological growth in the spirit of Romer (1986) naturally emphasise the influence of research and development (R\&D) on economic growth. But as Temple (1999) points out even though there is already an overhelming microeconomic evidence for high private returns to $R \& D$, there are some well-known problems in measuring the contribution of research to productivity growth. One reason for the difficulty to resolve research driven growth models is that the underlying concept of R\&D-models (the concept of knowledge and ideas) is so hard to pin down. ${ }^{4}$ Nevertheless, in empirical models one can try to proxy for R\&D through private and public expenditures on R\&D. Since international data for R\&D expenditures are not available before 1980, there is limited benefit in relating these expenditures to the growth experience of countries.

\subsection{Political and institutional setting}

The technological level of an economy determines the productivity of the inputs to production. Besides the technological efficiency under which an economy operates there is also the political and institutional setting that affects the overall productivity of an economy. In fact most variables in recent empirical growth studies that go beyond the analysis of the proximate sources of growth belong to this category. ${ }^{5}$ Especially two issues have obtained attention: Fiscal and monetary policy.

\footnotetext{
${ }^{4}$ See Temple (1999), p.140-141 for a full discussion

${ }^{5}$ For a systematical overview of variables used in empirical growth studies see Bassanini, Scarpetta and Hemmings (2001), Barro and Sala-i-Martin (2001), Durlauf and Quah (1999) or Sachverständigenrat (2002)
} 


\subsubsection{Inflation}

Though monetary policy is usually referred to through its impact on business-cycles, there could also be an impact on the long-run growth path via investment and investment uncertainty. Traditionally, the influence of inflation on growth is analysed through considerations of the influence of monetary growth changes on the level of the physical capital stock in the context of a neoclassical growth model. Tobin (1965) argues that inflation increases the opportunity cost of holding money and therefore encourages people to invest in physical capital. Temple (2000) points out that this should not be an important consideration since money balances are usually only a small fraction of the physical capital stock and therefore this effect of inflation on capital accumulation seems negligible. The effect mentioned by Tobin (1965) can even be reversed when altering assumptions: If money has to be held prior to the purchase of capital goods, inflation is expected to lower the steady-state capital stock. ${ }^{6}$ The effects of inflation on investment is becoming more important when considering endogenous growth theories in which returns to broad capital are constant.

A possibly stronger influence of inflation on investment is carried out through the tax system: An imperfectly indexed tax system increases the user cost of capital when inflation rises since the value of depreciation allowances falls at the same time. A higher user cost of capital increases the profitability required to undertake an investment project. Therefore, there should be an overall negative impact through inflation on the accumulation of physical capital and possibly steady-state growth. ${ }^{7}$

Besides the level of inflation also its variability could be connected to investment and growth through the impact on uncertainty. ${ }^{8}$ Arguments brought forward in this spirit are that inflation increases uncertainty and therefore introduces noise into the workings of markets.

Both the level of inflation and its variation will be considered in the empirical section of this paper.

\subsubsection{Government activity}

In terms of fiscal policy the role of government in setting the economic framework in which economic growth takes place is of major concern. Many publicly financed activities are not aimed to improve economic growth in the first place. The levy of social contributions in order to redistribute resources or the public stimulation of the demand side of the

\footnotetext{
${ }^{6}$ See Stockman (1981) for this argument

7 See Feldstein (1983)

${ }^{8}$ See Anh and Hemmings (2000) or Temple (2000) for an overview to this topic
} 
economy in times of weak overall demand are just two examples of government activities that do not aim to raise long-run growth but do follow wider policy objectives. Countries with huge public sectors may extend activities into areas that might be more efficiently carried out by private agents leading to productivity losses on the aggregate level. On the other hand there is Wagner's law which implies that the income elasticity of demand for government is larger than unity since the scope of government increases with the level of income. ${ }^{9}$ Therefore, in empirical investigation the observed correlation between income and government size may be positive. A priori, the expected sign of the relationship between government size and economic growth seems unclear.

The variables used in the econometric analysis are real government consumption as a proportion to GDP as well as the sum of direct and indirect taxes and social contributions received by government as a proportion to GDP. Real government consumption is more than just a proxy for a special component of public spending. This variable is often perceived as an indicator of government size and the importance of the public sector in the economy. ${ }^{10}$

Moreover, the government deficit will be considered.

\subsubsection{Taxes}

In terms of the composition of public revenues it is useful to distinguish between distortionary taxes (direct taxes, e.g. taxes on income and firm profits) and taxes that are generally regarded as less distortionary (indirect taxes, taxation of goods and services). Distortionary taxes could affect the investment decision in physical and human capital of agents and hence lower growth, while non-distortionary taxes do not influence preferences of economic agents. ${ }^{11}$ For example, if labour supply is inelastic, the intertemporal consumption path of an agent is not influenced by a consumption tax or a flat tax on labour income. Since not all taxes may be equally distorting, the tax mix is possibly an important growth determinant. ${ }^{12}$ In this paper it will be accounted for via the taxratio variable (the proportion of total indirect taxes to total direct taxes).

\footnotetext{
${ }^{9}$ See Fölster and Henrekson (2001) for a deeper discussion of Wagner's law and the role of government for economic growth

${ }^{10}$ See e.g. Sachverständigenrat (2002), pp 519

${ }^{11}$ For further arguments see among others Widmalm (2001), Padovano and Galli (2002) or Milesi-Ferretti and Roubini (1998)

12 See e.g. Widmalm (2001), p. 201 for this rationale
} 


\subsubsection{Labour markets}

Another source for influences on economic growth is the institutional design of national labour markets. Especially labour market rigidities are likely to affect the growth rate negatively because they lead to underutilisation of the human capital stock. De La Fuente (2003) notes, since the underlying theoretical models of empirical growth-studies describe the evolution of labour productivity (i.e. output per employed worker), it should be expected that the growth of income per capita will also depend on the behaviour of participation and unemployment rates. Hence the empirical model of this paper which also uses GDP per capita as independent variable will incorporate a measure for the non-cyclical unemployment rate, namely the NAWRU (Non-Accelerating Wage Rate of Unemployment), which is estimated by the OECD.

\subsection{International trade}

The next sphere of influence on growth to be considered is international trade. The economic literature has several arguments why engagement in international trade could be beneficial for an economy. The traditional reasoning is that trade is beneficial because of the exploitation of comparative advantages. But there are other arguments brought forward. The exposure to competition through openness or the diffusion of technology through trade can improve the economic growth of a country. ${ }^{13}$ But trade can also be just a reflection of growth patterns in the sense that trade is endogenous to the growth progress. ${ }^{14}$ To proxy for the trade openness of a country the share of exports and imports to GDP is used in the empirical analysis. Furthermore, to capture trade effects as a result of price advantages or disadvantages, an indicator of the terms of trade (export prices over import prices) is accounted for.

\subsection{Financial markets}

A special strand of the growth literature focuses on the relationship between financial market development and economic growth. Pagano (1993) gives a comprehensive overview of this issue. These theories emphasise the efficiency with regard to information processing of highly developed financial markets. Financial markets collect and distribute information concerning investment projects efficiently and allow investors to pool risks through the allocation of various financial assets. Especially concerning the funding of new technologies, stock markets seem to be

\footnotetext{
${ }^{13}$ See Coe and Helpman (1995) for the role of trade for technological diffusion

${ }^{14}$ See for example Baldwin (2000)
} 
superior to credit funding through the efficient allocation of information. ${ }^{15}$ Besides the gains in overall efficiency, developed financial markets may increase the level of investments through the provision of attractive assets. The empirical literature is somewhat ambiguous about the growth enhancing properties of financial markets when considering industrial countries. ${ }^{16}$ In this paper the traditional set of indicators to proxy for the influence of financial markets is used: The stock market capitalisation of listed companies to GDP as an indicator of relative development and size of a stock market. Furthermore, the total value of stocks traded as a fraction of GDP to proxy for stock market liquidity. Also the turnover which is defined as the ratio of stocks traded to market capitalisation is considered as a proxy for market liquidity. In order to account for the influence of credit markets the variable of total credits to the private sector over GDP is also included.

\subsection{Demography}

The last issue to be considered is demography and the consequences of an aging population on growth. There are different arguments why aging could influence the growth path. On the hand there are influences on the input factors to production. The relative provision of inputs is likely to change under an aging society since the relative labour force is decreasing leading to an increased capital-labour ratio. This could lead to a disinvestment of physical capital since the ratio of capital to labour needs to be adjusted leading to slower rates of GDP-growth. There could also be influences of an aging population on the rate of technological progress if innovations and technological adaptation are exacerbated by an older population which human capital is sufficiently depreciated. ${ }^{17}$ But empirical evidence for those theories is flawed by the fact that no country has undergone the whole process of aging so far. Nevertheless, these ideas are incorporated in the empirical section through the variable of age dependency and the variable of the proportion of the population over the age of 65 to total population.

Of course the just described wider sources of growth constitute by no means a complete set of growth-enhancing or growth-impeding variables. Instead this set of variables is intended to bundle the most evident record of the theoretical and empirical growth literature. A complete list of the variables used in this paper and the corresponding data sources can be found in the appendix. The next section explains the empirical model and the econometric approach.

\footnotetext{
${ }^{15}$ See Allen and Gale (2000) for this reasoning

16 See Hahn (2002)

17 See Siebert (2002) for further arguments
} 


\section{Empirical model and econometric approach}

The empirical model follows partly Bassanini, Scarpetta and Hemmings (2001). The approach is briefly reviewed and the dynamic equation employed in the empirical testing is derived.

\subsection{Derivation of steady-state dynamics}

The model is derived from a standard neoclassical approach that builds around a constant returns to scale production function with three inputs (labour, physical and human capital). ${ }^{18}$ The aggregate production function for a country is (subscripts for cross-sections are omitted due to notational convenience)
(1) $Y_{t}=K_{t}^{\alpha} H_{t}^{\beta}\left(A_{t} L_{t}\right)^{1-\alpha-\beta}$
$\alpha, \beta>0$,
$\alpha+\beta<1$

$\mathrm{Y}_{\mathrm{t}}$ is aggregate production, $\mathrm{K}_{\mathrm{t}}$ the stock of physical capital, $\mathrm{L}_{t}$ labour input, $H_{t}$ the stock of human capital and $A_{t}$ the Harrod-neutral level of economic and technological efficiency. The partial elasticities of output in regard to its inputs are respectively $\alpha$ and $\beta$.

The dynamics of physical capital, human capital and labour are as follows ${ }^{19}$ :

(2) $\dot{K}_{t}=s_{t}^{K} Y_{t}-\delta K_{t}$

(3) $\dot{\mathrm{H}}_{\mathrm{t}}=\mathrm{s}_{\mathrm{t}}^{\mathrm{H}} \mathrm{Y}_{\mathrm{t}}-\delta \mathrm{H}_{\mathrm{t}}$

(4) $\dot{\mathrm{L}}_{\mathrm{t}}=\mathrm{n}_{\mathrm{t}} \mathrm{L}_{\mathrm{t}}$

$\mathrm{S}_{\mathrm{t}}^{\mathrm{K}}$ is the fraction of output that is invested in physical capital and $\mathrm{s}_{\mathrm{t}}^{\mathrm{H}}$ is the fraction that is invested in human capital. Population grows at the exogenous rate $n_{t}$. Physical and human capital depreciate at the same rate of $\delta^{20}$. The level of economic and technological efficiency $A_{t}$ consists of two components: economic efficiency $I_{t}$ and the level of technological progress $\Omega_{\mathrm{t}}$ :

(5) $A_{t}=I_{t} \Omega_{t}$

18 See also Mankiw, Romer and Weil (1992) or Islam (1995) for this attempt

${ }^{19}$ Dotted variables represent derivatives with respect to time

${ }^{20}$ See Mankiw, Romer and Weil (1992), p. 416 for a justification of this assumption. 
The level of technological progress grows at the exogenous rate $g_{t}$ :

(6) $\dot{\Omega}_{t}=g_{t} \Omega_{t}$

whereas the level of economic efficiency is a log-linear function of institutional and policy variables $\mathrm{V}_{\mathrm{jt}}$ (the variables and indicators described in the previous section): ${ }^{21}$

(7) $\ln \mathrm{I}_{\mathrm{t}}=\mathrm{p}_{0}+\sum_{\mathrm{j}} \mathrm{p}_{\mathrm{j}} \ln \mathrm{V}_{\mathrm{jt}}$

Let $\mathrm{y}=\mathrm{Y} / \mathrm{AL}, \mathrm{k}=\mathrm{K} / \mathrm{AL}$ and $\mathrm{h}=\mathrm{H} / \mathrm{AL}$ be quantities per effective unit of labour. Since $\alpha+\beta<1$ the economy converges to a steady state defined by

(8) $\mathrm{k}_{\mathrm{t}}^{*}=\left(\frac{\left(\mathrm{s}_{\mathrm{t}}^{\mathrm{K}}\right)^{1-\beta}\left(\mathrm{s}_{\mathrm{t}}^{\mathrm{H}}\right)^{\beta}}{\mathrm{n}_{\mathrm{t}}+\mathrm{g}_{\mathrm{t}}+\delta}\right)^{\frac{1}{1-\alpha-\beta}}$ and $^{22}$

(9) $h_{t}^{*}=\left(\frac{\left(s_{t}^{K}\right)^{\alpha}\left(s_{t}^{H}\right)^{1-\alpha}}{n_{t}+g_{t}+\delta}\right)^{\frac{1}{1-\alpha-\beta}}$.

Substituting these expressions into the production function and taking logarithms gives an equation for output per capita in steady state:

$$
\begin{aligned}
& \ln \left(\frac{Y_{t}}{L_{t}}\right)^{*}=\ln \Omega_{t}+p_{0}+\sum_{j} p_{j} \ln V_{j t}+\frac{\alpha}{1-\alpha-\beta} \ln s_{t}^{K} \\
& +\frac{\beta}{1-\alpha-\beta} \ln s_{t}^{H}-\frac{\alpha+\beta}{1-\alpha-\beta} \ln \left(g_{t}+n_{t}+\delta\right)
\end{aligned}
$$

Output per capita in steady-state depends on the accumulation of physical and human capital, population growth, the rate of technological

${ }^{21}$ See Bassanini, Scarpetta and Hemmings (2001), p. 51

${ }^{22}$ Star superscripts denote steady state values. For a more rigorous derivation see Mankiw, Romer and Weil (1992), pp.416-418 
progress, the rate of depreciation and the level of institutional and political efficiency. Equation (10) describes the evolution of the level of output per capita in the long-run. Observed growth rates usually include out-of-steady state dynamics that need to be accounted for in empirical application.

\subsection{Time-series properties of the data: unit root tests}

The panel data set in this study covers at most 23 countries over $30^{23}$ years, whereas not all variables are observed for all 23 countries. ${ }^{24}$ The time-series of this data set are regularly characterised by trends and non-stationarity. These properties have to be accounted for in econometric estimation. In order to test the non-stationarity of the variables individual unit root tests as well as panel unit root tests are used. On the individual level, augmented Dickey-Fuller-Tests (ADF) ${ }^{25}$ are applied whereas for the panel tests the method of Im, Pesaran and Shin (2002, IPS hereafter) is used. The IPS-test is based on the average of (augmented) Dickey-Fuller (1979) statistics computed for each group in the panel, allowing for residual serial correlation and heterogeneity of the dynamics and error variances across groups. IPS (2002) refer to this statistic as the t-bar test. After moment adjustment of this t-bar statistic, the standardised Zt-bar is shown to converge in probability to a standard normal variate sequentially with $\mathrm{T} \rightarrow \infty$, followed by $\mathrm{N} \rightarrow \infty .{ }^{26}$ The pair of hypothesis of the IPS-test can be stated as

$$
H_{0}: \rho_{i}=0 \forall i \quad H_{1}:\left\{\begin{array}{l}
\rho_{i}=0 \text { for } i=1, \ldots, N_{1} \\
\rho_{i}<0 \text { for } i=N_{1}+1, \ldots, N
\end{array}\right.
$$

with $\rho_{\mathrm{i}}$ as autoregressive coefficient of the ith-country of the underlying ADF-test. $\mathrm{N}$ is the overall cross-section dimension while $\mathrm{N}_{1}$ denotes a subset of $\mathrm{N}$. Note that under $\mathrm{H}_{1}$ rejection of the null hypothesis does not necessarily imply that the unit root null is rejected for all $\mathrm{i}$, but only that the null hypothesis is rejected for $\mathrm{N}_{1}<\mathrm{N}$ members of the group such

\footnotetext{
${ }^{23}$ Following Quah (1993), this data set with great N and T can be called „data field“

${ }^{24}$ Especially when considering variables related to fiscal policy and labour markets, the cross-section dimension reduces to 12 countries since only a subset of the member countries of the OECD report figures. See table $1 \mathrm{~A}$ in the appendix for detailed information.

${ }^{25}$ See Dickey and Fuller (1979)

${ }^{26}$ See Im, Pesaran and Shin (2002), theorem 3.1., p. 6
} 
that as $\mathrm{N} \rightarrow \infty, \mathrm{N}_{1} / \mathrm{N} \rightarrow \mathrm{v}>0 .{ }^{27}$ The test procedure however does not provide any guidance as to the magnitude of $\mathrm{V}$, in the sense that it does not allow for conclusion of the members for which the null hypothesis is rejected. Therefore, special care needs to be exercised when interpreting these results. However, individual unit root test can give guidance for the magnitude of $\mathrm{V}$. Therefore, the order of integration of the variables is assessed both on the grounds of individual and panel unit root tests.

\subsection{Panel Error Correction Model (ECM) and estimation}

The determination of the order of integration for the variables is important for setting up the cointegration analysis. If there is a linear combination of two or more non-stationary series that is stationary, the non-stationary time-series are said to be cointegrated. ${ }^{28}$ This stationary combination can be interpreted as long-run equilibrium. Therefore, only the non-stationary series will enter the cointegration relationship, all stationary series will enter as exogenous variables in the estimation of the corresponding ECM.

Before applying cointegration analysis, the notion of panel ECMs and the specific empirical equation used in this paper is explained. The coverage of the data allows in principle to estimate $\mathrm{N}$ separate regressions or $\mathrm{N}$ separate ECMs. But the aim here is to exploit the cross-sectional dimension of the data to gain more precise estimates of the long-run relationship. $^{29}$

Denoting $\mathrm{y}_{\mathrm{it}}=\mathrm{Y}_{\mathrm{it}} / \mathrm{L}_{\mathrm{it}}(\mathrm{i}=1, \ldots, \mathrm{N}, \mathrm{T}=1, \ldots, \mathrm{T})$ as output per capita for country $\mathrm{i}$, equation (10) can be stated as panel ECM:

$$
\begin{aligned}
\Delta \ln \mathrm{y}_{\mathrm{it}}= & -\phi_{\mathrm{i}}\left(\ln \mathrm{y}_{\mathrm{it}-1}-\mathrm{a}_{1 \mathrm{i}} \ln \mathrm{s}_{\mathrm{it}}^{\mathrm{K}}-\mathrm{a}_{2 \mathrm{i}} \ln \mathrm{s}_{\mathrm{it}}^{\mathrm{H}}+\mathrm{a}_{3 \mathrm{i}} \mathrm{n}_{\mathrm{it}}+\mathrm{a}_{4 \mathrm{i}} \mathrm{t}_{\mathrm{i}}-\mathrm{a}_{\mathrm{i} 0}-\sum_{\mathrm{j}=5}^{\mathrm{m}} \mathrm{a}_{\mathrm{ji}} \ln \mathrm{V}_{\mathrm{it}}^{\mathrm{j}}\right) \\
& +\sum_{\mathrm{k}_{0}=1}^{\mathrm{K}_{0}} \mathrm{~b}_{0 \mathrm{ik}_{0}} \Delta \ln \mathrm{y}_{\mathrm{it}-\mathrm{k}_{0}}+\sum_{\mathrm{k}_{1}=0}^{\mathrm{K}_{1}} \mathrm{~b}_{1 \mathrm{ik}} \Delta \ln \mathrm{s}_{\mathrm{it}-\mathrm{k}_{1}}^{\mathrm{K}}+\sum_{\mathrm{k}_{2}=0}^{\mathrm{K}_{2}} \mathrm{~b}_{2 \mathrm{ik}_{2}} \Delta \ln \mathrm{s}_{\mathrm{it}-\mathrm{k}_{2}}^{\mathrm{H}} \\
& +\sum_{\mathrm{k}_{3}=0}^{\mathrm{K}_{3}} \mathrm{~b}_{3 \mathrm{ik}_{3}} \Delta \mathrm{n}_{\mathrm{it}-\mathrm{k}_{3}}+\sum_{\mathrm{j}=4}^{\mathrm{m}} \sum_{\mathrm{k}_{4}=0}^{\mathrm{K}_{4}} \mathrm{~b}_{\mathrm{ik}_{4}}^{\mathrm{j}} \Delta \ln \mathrm{V}_{\mathrm{it}-\mathrm{k}_{4}}^{\mathrm{j}}+\varepsilon_{\mathrm{it}}
\end{aligned}
$$

\footnotetext{
${ }^{27}$ See Im, Pesaran and Shin (2002), p. 14

${ }^{28}$ See Engle and Granger (1987)

${ }^{29}$ Baltagi and Griffin (1997) for example argue that the efficiency gains of pooling the data outweigh the losses from the bias induced by heterogeneity.
} 
The first term in brackets on the right hand side of equation 11 is the long-run equilibrium of equation 10. A deterministic time trend $\left(t_{i}\right)$ is included to account for the exogenous growth of technological progress. Note that inclusion of variables in the long-run equilibrium depends on the time-series properties of the specific variables. Stationary variables will enter as exogenous variable while integrated variables will enter the long-run relationship. Lagged differences of the endogenous variables are included to capture short-run adjustment dynamics (remaining terms of equation 11). The $\varepsilon_{\mathrm{it}}$ are cross-section specific error terms. The loading parameters $\phi_{i}$ are country-specific measures of the speed of adjustment to equilibrium. These parameters can be interpreted as the velocity of how fast an economy will return to long-run growth once deviated from that path because of e.g. business-cycle movements.

Due to the logarithm-transformation, parameters of the long-run equilibrium coefficients $\left(\mathrm{a}_{1 \mathrm{i}}, \mathrm{a}_{2 \mathrm{i}}, \ldots, \mathrm{a}_{\mathrm{mi}}\right)$ can be interpreted as elasticities of the respective variable with respect to output per capita. For example, the estimated elasticity of steady-state output per capita to the investment rate for country $i$ is given by $a_{1 i}$.

In growth empirics it is common to analyse just the cross-section dimension. Also, assumptions about common growth factors - at least in country-samples that share similar characteristics (western industrial countries with market economies for example) - seem to be appropriate. In terms of short-run dynamics, this assumption seems rather implausible. Pesaran, Shin and Smith (1999, PSS hereafter) propose an estimator that allows pooling the coefficients along the long-run relationship while allowing the short-run dynamics to be heterogeneous. They call this procedure Pooled Mean Group Estimation and the corresponding set of estimated parameters Pooled Mean Group Estimator (PMGE hereafter).

In terms of equation (11), applying the PMGE imposes following homogeneity restrictions on the long-run parameters:

$$
a_{1 i}=a_{1}, a_{2 i}=a_{2}, \ldots, a_{m i}=a_{m} \quad \forall i, i=1, \ldots, N
$$

While the homogeneity restrictions are imposed for the steady-state equation, short-run dynamics are estimated heterogeneously to allow for different business-cycles adjustment patterns across countries. 
The PMGEs are obtained by maximising the concentrated log-likelihood function belonging to the ECM specification (11) under the restriction (12) and the assumption that the disturbances $\varepsilon_{i t}$ are independently distributed across $\mathrm{i}$ and $\mathrm{t}$ with zero means and variances $\sigma_{\mathrm{i}}^{2}$. Furthermore, the model needs to be stable in the sense that the roots of the characteristic equation of the steady-state fall outside the unit circle. ${ }^{30}$ In order to test for the homogeneity restriction (12), PSS (1999) propose a Hausman (1978)-type test. This test is based on comparing the consistent estimates of the Mean Group estimator (MGE) with the estimated coefficients of the PMGE. The MGE averages the individual country estimates. Under homogeneity, the mean and the individual parameters coincide and the PMGE are consistent and more efficient. The test statistic is given by

$$
H=\hat{o}^{\prime}[\operatorname{var}(\hat{o})]^{-1} \hat{o}
$$

where $\hat{O}$ is $a(m \times 1)$ vector of the differences between the MGE and PMGE coefficients and $\operatorname{var}(\hat{\mathrm{o}})$ is the corresponding covariance matrix. Under the homogeneity hypothesis of the long-run equilibrium, the Hausman (1978) statistic (13) is asymptotically distributed as $\chi^{2}$ variate with $\mathrm{m}$ degrees of freedom, the number of estimated long-run parameters. Since $\operatorname{var}(\hat{0})$ need not to be positive definite, in some cases the test may not be applicable.

\subsection{Cointegration testing}

After applying the PMGE, the estimated long-run relationship needs to be tested for cointegration.

Cointegration analysis in this paper is carried out using Pedronis (1999) method to test for cointegration in heterogeneous panels with multiple regressors. Basically, this test is the panel analogue to the residual based cointegration tests in single country analysis of Engle and Granger (1987). The advantage of the panel cointegration test is that the test statistics tend to converge to a normal distribution as the cross-section dimension increases and power usually increases as well.

The Pedroni (1999) test is based on testing the order of integration of the residuals of the cointegration regression, which may take the (most general) form ${ }^{31}$

30 See Pesaran, Shin and Smith (1999), p.624

${ }^{31}$ See Pedroni (1999), p. 656 


$$
\mathrm{y}_{\mathrm{it}}=\alpha_{\mathrm{i}}+\eta_{\mathrm{i}} \mathrm{t}+\beta_{1 \mathrm{i}} \mathrm{x}_{1 \mathrm{it}}+\beta_{2 \mathrm{i}} \mathrm{x}_{2 \mathrm{it}}+\ldots+\beta_{\mathrm{mi}} \mathrm{x}_{\mathrm{mit}}+\mathrm{e}_{\mathrm{it}}
$$

Pedroni (1999) offers seven statistics to test if the autoregressive coefficient of the residual based regression is unity. Four test-statistics pool the autoregressive coefficient $(\gamma)$ along the so called withindimension, while three statistics pool along the between-dimension by taking the average of the coefficients. The four statistics that refer to the within-dimension have following hypothesis

$$
H_{0}(\text { No cointegration }): \gamma_{i}=1 \quad \forall i, \quad H_{1}: \gamma_{i}=\gamma<1 \quad \forall i
$$

Note that under $\mathrm{H}_{0}$ as well as under $\mathrm{H}_{1}$ these statistics assume a common value for the autoregressive coefficient $\gamma$ of the underlying residual regression.

By contrast, the test statistics of the between-dimension allow for an additional source of potential heterogeneity, since they do not assume a common autoregressive coefficient on the residual test. The hypothesises are

$$
H_{0} \text { (No cointegration) }: \gamma_{i}=1 \quad \forall i, \quad H_{1}: \gamma_{i}<1
$$

Pedroni (1999) refers to the four within test statistics as panel cointegration statistics and to the three between test statistics as group mean panel cointegration statistics. The panel cointegration statistics are a variance bounds test ( $v$-statistic), an analogue to the Phillips Peron $\rho$ test (panel $\rho$-statistic) and nonparametric Phillips-Peron (1988) test (panel PP-statistic) and a parametric ADF statistics (panel ADF-statistic). The group tests are the group $\rho$-statistics, the group PP-statistic and the group ADF-statistic. ${ }^{32}$ These (one sided) test statistics are distributed asymptotic standard normal.

The next section presents empirical results to all of these tests.

${ }^{32}$ See Pedroni (1999), pp 660 for exact calculation of these statistics 


\section{Empirical results and Interpretation}

First of all the results of the individual and panel unit root tests are discussed. ${ }^{33}$ Since the data set covers many variables, only the outcomes of variables of the basic model are described in detail. ${ }^{34}$ All other results are summarised in the appendix, table 2A. A complete list of the data set can be found in table $1 \mathrm{~A}$ in the appendix.

\subsection{Unit root test results}

For individual unit root tests and for panel unit root tests, it is critical to decide whether to include deterministic regressors like a constant or trend or not since the asymptotic distribution of the test statistics is influenced by that choice. Since none of the variables variate around a zero mean, the inclusion of a constant was always appropriate. For the choice of inclusion of a deterministic time trend, this was done on grounds of a graphical inspection of the individual series: Whenever the majority of the individual series seems to follow a linear trend, a trend was included in the panel unit root test. Otherwise it was left out.

Table 1 shows the results of individual ADF-tests for the log of real GDP per capita. The column denoted "Lag" gives the selected number of lagged differences included in the ADF-regression according to the modified Schwarz-criterion. ${ }^{35}$ The ADF-regressions included a time trend.

Table 1: Individual unit root tests for $\log (y)$

Null Hypothesis: Unit root (individual unit root process)

Time period: 1971 to 2000

Exogenous variables: Individual effects, individual linear trends

\begin{tabular}{|cccc|cccc|} 
Cross-section & t-Stat & Prob. $^{*}$ & Lag & Cross-section & t-Stat & Prob.* & Lag \\
\hline AUS & -1.4270 & 0.8318 & 0 & ITA & -3.3104 & 0.0852 & 2 \\
AUT & -2.5355 & 0.3100 & 3 & JPN & -2.4680 & 0.3401 & 1 \\
BEL & -2.4364 & 0.3549 & 0 & KOR & -2.2409 & 0.4513 & 0 \\
CHE & -3.5654 & 0.0509 & 1 & LUX & -1.0182 & 0.9262 & 0 \\
DEU & -2.8073 & 0.2057 & 0 & NLD & -0.8276 & 0.9511 & 1 \\
DNK & -2.8837 & 0.1828 & 3 & NOR & -2.8661 & 0.1872 & 1 \\
ESP & -3.1222 & 0.1201 & 1 & NZL & -1.9696 & 0.5936 & 0 \\
FRA & -3.0278 & 0.1428 & 2 & PRT & -1.7022 & 0.7213 & 4 \\
GBR & -2.4665 & 0.3408 & 1 & SWE & -3.6476 & 0.0430 & 1 \\
GRC & -2.7454 & 0.2273 & 1 & TUR & -2.8907 & 0.1794 & 0 \\
IRE & 1.2566 & 0.9999 & 0 & USA & -2.6057 & 0.2806 & 1 \\
ISL & -1.9264 & 0.6152 & 1 & & & & \\
\hline
\end{tabular}

*: MacKinnon (1996) one sided p-values

\footnotetext{
${ }^{33}$ Eviews 5.0 was used for individual and panel unit root tests.

${ }^{34}$ The variables of the basic model are real GDP per capita, investment/GDP, human capital and population growth.

35 See $\mathrm{Ng}$ and Perron (2000) for a discussion of modified information criteria
} 
The results are clear-cut: Except for Sweden, for none of the countries the null hypothesis of a unit root can be rejected at the 5\%-significance level. This finding is confirmed by the panel unit root tests (see table 2 ). On the other hand, first differences of the log of GDP per capita are stationary, confirming that this variables are integrated once.

Table 2: Summary of panel unit root tests (IPS-test) for the variables of the basic model

\begin{tabular}{|c|c|c|c|c|c|}
\hline \multirow[b]{2}{*}{ Variable } & \multicolumn{2}{|c|}{ Exogenous variables } & \multirow{2}{*}{$\begin{array}{l}\text { Zt-bar- } \\
\text { statistic }\end{array}$} & \multirow[b]{2}{*}{ Probability } & \multirow{2}{*}{$\begin{array}{l}\text { No. of } \\
\text { obs. }\end{array}$} \\
\hline & $\begin{array}{c}\text { Individual } \\
\text { effects }\end{array}$ & $\begin{array}{l}\text { Individual } \\
\text { linear trend }\end{array}$ & & & \\
\hline $\log (y)$ & Yes & Yes & -0.92740 & 0.1769 & 666 \\
\hline$\Delta \log (\mathrm{y})$ & Yes & No & -13.7269 & 0.0000 & 655 \\
\hline $\log (s k)$ & Yes & No & $\begin{array}{l}-0.81391 \\
\end{array}$ & 0.2078 & 682 \\
\hline$\Delta \log (\mathrm{sk})$ & Yes & No & -8.66923 & 0.0000 & 647 \\
\hline $\begin{array}{c}\log (\mathrm{sh}) \\
\Delta \log (\mathrm{sh})\end{array}$ & $\begin{array}{l}\text { Yes } \\
\text { Yes }\end{array}$ & $\begin{array}{l}\text { Yes } \\
\text { No }\end{array}$ & $\begin{array}{r}2.21115 \\
-8.62234 \\
\end{array}$ & $\begin{array}{l}0.9865 \\
0.0000\end{array}$ & $\begin{array}{l}668 \\
635 \\
\end{array}$ \\
\hline $\mathrm{n}$ & Yes & No & -6.78102 & 0.0000 & 690 \\
\hline
\end{tabular}

Also investment (as a fraction of GDP) is integrated of order one according to individual and panel unit root results (see table 3 and 2).

Table 3: Individual unit root tests for log(sk)

Null Hypothesis: Unit root (individual unit root process)

Time period: 1971 to 2000

Exogenous variables: Individual effects

\begin{tabular}{|cccc|cccc|} 
Cross-section & t-Stat & Prob. $^{*}$ & Lag & Cross-section & t-Stat & Prob.* & Lag \\
\hline AUS & -2.1754 & 0.2188 & 0 & ITA & -2.2394 & 0.1974 & 0 \\
AUT & -1.5220 & 0.5090 & 0 & JPN & -1.5449 & 0.4976 & 0 \\
BEL & -1.7711 & 0.3869 & 0 & KOR & -2.6494 & 0.0955 & 2 \\
CHE & -0.8991 & 0.7722 & 4 & LUX & -2.4518 & 0.1370 & 0 \\
DEU & -2.3433 & 0.1658 & 0 & NLD & -3.0777 & 0.0392 & 0 \\
DNK & -1.7237 & 0.4096 & 0 & NOR & -0.7743 & 0.8120 & 0 \\
ESP & -1.0739 & 0.7128 & 0 & NZL & -1.9734 & 0.2963 & 0 \\
FRA & -1.4428 & 0.5481 & 0 & PRT & -1.0473 & 0.7229 & 0 \\
GBR & -1.4769 & 0.5313 & 0 & SWE & -1.9255 & 0.3167 & 0 \\
GRC & -1.8105 & 0.3684 & 0 & TUR & -1.8106 & 0.3684 & 0 \\
IRE & -1.3577 & 0.5892 & 0 & USA & 0.1979 & 0.9675 & 2 \\
ISL & -1.4067 & 0.5657 & 0 & & & & \\
\hline
\end{tabular}

*: MacKinnon (1996) one sided p-values

In terms of human capital, results on the individual level are not entirely clear-cut. For three countries (Australia, Denmark and Italy) the null hypothesis is rejected at the 5\%-level. However, according to the panel unit root result, there is no doubt that human capital can be regarded as integrated of order one (see table 4 and 2). 
Table 4: Individual unit root tests for log(sh)

Null Hypothesis: Unit root (individual unit root process)

Time period: 1971 to 2000

Exogenous variables: Individual effects, individual linear trends

\begin{tabular}{|cccc|cccc|} 
Cross-section & t-Stat & Prob. $^{*}$ & Lag & Cross-section & t-Stat & Prob. $^{*}$ & Lag \\
\hline AUS & -1.8391 & 0.6603 & 0 & ITA & -5.5154 & 0.0005 & 0 \\
AUT & -3.5670 & 0.0501 & 0 & JPN & 0.6495 & 0.9993 & 0 \\
BEL & -1.7098 & 0.7218 & 0 & KOR & -2.4868 & 0.3317 & 0 \\
CHE & -0.1760 & 0.9897 & 6 & LUX & -1.1910 & 0.8943 & 0 \\
DEU & -0.8233 & 0.9507 & 3 & NLD & -2.0668 & 0.5425 & 0 \\
DNK & -4.3625 & 0.0086 & 0 & NOR & -2.0888 & 0.5309 & 0 \\
ESP & -2.3085 & 0.4169 & 0 & NZL & -0.2491 & 0.9875 & 6 \\
FRA & -1.7221 & 0.7162 & 0 & PRT & -1.9126 & 0.6231 & 0 \\
GBR & -0.8684 & 0.9468 & 0 & SWE & -1.3572 & 0.8529 & 0 \\
GRC & -2.3359 & 0.4016 & 4 & TUR & -0.9480 & 0.9366 & 0 \\
IRE & -0.6378 & 0.9689 & 0 & USA & -1.2764 & 0.8745 & 0 \\
ISL & -0.9639 & 0.9328 & 3 & & & & \\
\hline
\end{tabular}

*: MacKinnon (1996) one sided p-values

The results for Population growth are ambiguous on the individual level: 11 out of 23 countries indicate stationarity for population growth at a 5\%significance level (see table 5).

Table 5: Individual unit root tests for $n$

Null Hypothesis: Unit root (individual unit root process)

Time period: 1971 to 2000

Exogenous variables: Individual effects, individual linear trends

\begin{tabular}{|cccc|cccc|} 
Cross-section & t-Stat & Prob. $^{*}$ & Lag & Cross-Section & t-Stat & Prob.* & Lag \\
\hline AUS & -3.4667 & 0.0162 & 0 & ITA & -2.1465 & 0.2290 & 0 \\
AUT & -3.9097 & 0.0056 & 1 & JPN & -1.0987 & 0.7031 & 1 \\
BEL & -2.3961 & 0.1512 & 0 & KOR & -0.1151 & 0.9389 & 0 \\
CHE & -5.8966 & 0.0000 & 4 & LUX & -4.1138 & 0.0033 & 3 \\
DEU & -5.2777 & 0.0002 & 0 & NLD & -0.0940 & 0.9414 & 2 \\
DNK & -3.6549 & 0.0104 & 3 & NOR & -3.1247 & 0.0353 & 1 \\
ESP & -3.1311 & 0.0349 & 0 & NZL & -2.7208 & 0.0823 & 1 \\
FRA & -1.1633 & 0.6768 & 0 & PRT & -3.2920 & 0.0243 & 0 \\
GBR & -2.1480 & 0.2285 & 0 & SWE & -4.1893 & 0.0028 & 1 \\
GRC & -3.6515 & 0.0105 & 0 & TUR & -2.8225 & 0.0671 & 0 \\
IRE & -1.8206 & 0.3638 & 0 & USA & -2.6057 & 0.4599 & 0 \\
ISL & -2.2869 & 0.1824 & 0 & & & & \\
\hline
\end{tabular}

*: MacKinnon (1996) one sided p-values

The panel outcome however is unambiguous. The IPS-tests refuses the null hypothesis of non-stationarity. Therefore, this time-series is modelled as stationary variable throughout the remaining empirical estimations. As mentioned before, detailed test results for the whole set of variables is skipped. Table 2A in the appendix summarises the time-series properties of the complete data set. 


\subsection{Estimation Results for the Panel-ECMs}

\subsubsection{Estimation results for the basic model}

After determining the order of integration for the respective variables, the basic model consisting of real GDP per capita, the investment share, human capital and population growth was estimated along the lines of PSS (1999). ${ }^{36}$ Since Population growth is stationary, it will enter the panel ECM as exogenous variable. To account for the German reunification in 1990 and the induced level shift of GDP per capita, an impulse dummy was included as exogenous variable in the estimation. Table 6 displays the PMGE and the MGE estimation results. ${ }^{37}$

Table 6: PMGE results for the basic model

\begin{tabular}{|c|c|c|c|c|c|c|}
\hline \multirow[t]{2}{*}{ Variable } & \multicolumn{3}{|c|}{ Pooled MGE estimates } & \multicolumn{3}{|c|}{ MGE estimates } \\
\hline & Coeff. & Std.Err. & t-ratio & Coeff. & Std.Err. & t-ratio \\
\hline \multicolumn{7}{|c|}{ Long-run coefficients } \\
\hline $\log (\mathrm{sk})$ & 0.229 & 0.020 & 11.161 & 0.287 & 0.086 & 3.344 \\
\hline $\log (\mathrm{sh})$ & 0.107 & 0.024 & 4.503 & 0.351 & 0.226 & 1.557 \\
\hline & & & & \multicolumn{3}{|c|}{ Joint Hausman test } \\
\hline & \multicolumn{6}{|c|}{ Error correction coefficients } \\
\hline $\log (y(-1))$ & -0.421 & 0.111 & -3.800 & -0.468 & 0.110 & -4.252 \\
\hline & \multicolumn{6}{|c|}{ Short-run coefficients } \\
\hline$\Delta \log (\mathrm{y}(-1))$ & 0.136 & 0.065 & 2.080 & 0.098 & 0.083 & 1.185 \\
\hline$\Delta \log (\mathrm{sk})$ & 0.152 & 0.063 & 2.414 & 0.141 & 0.069 & 2.031 \\
\hline$\Delta \log (\operatorname{sk}(-1))$ & -0.006 & 0.024 & -0.232 & -0.021 & 0.037 & -0.568 \\
\hline$\Delta \log (\mathrm{sh})$ & -0.128 & 0.089 & -1.432 & -0.101 & 0.064 & -1.576 \\
\hline$\Delta \log (\operatorname{sh}(-1))$ & -0.007 & 0.015 & -0.490 & 0.003 & 0.017 & 0.186 \\
\hline Dummy (91=1) & 0.004 & 0.004 & 0.965 & -0.002 & 0.003 & -0.927 \\
\hline Linear Trend & 0.007 & 0.002 & 3.443 & 0.008 & 0.002 & 3.513 \\
\hline $\mathrm{n}$ & -0.010 & 0.005 & -1.897 & -0.007 & 0.004 & -1.784 \\
\hline Intercept & 4.591 & 1.111 & 4.131 & 5.237 & 1.179 & 4.442 \\
\hline
\end{tabular}

Time period: 1971 to 2000 , Number of cross-sections $=12$

This estimation includes 12 countries (Austria, Belgium, Germany, Denmark, France, United Kingdom, Italy, Japan, Netherlands, Norway, Sweden and the USA). These countries have observations for all variables of the data set and make up the largest possible intersection. Even though the cross-section dimension for estimating the basic model

\footnotetext{
${ }^{36}$ Note that except for population growth, all variables enter the estimations as logarithm

${ }^{37}$ I am grateful to Yongcheol Shin for making a Gauss procedure available.
} 
could span all 23 countries, results are better comparable with the subsequent estimations of augmented growth models, which rely on smaller samples due to data availability.

Further remarks on table 6 are necessary: The first column contains the PMGE while the second contains the MGE. The Hausman-test is based on comparing these coefficients. The long-run coefficients should be obvious: These coefficients are the elasticities of output with respect to the explanatory variables of the long-run relationship. The magnitude of these elasticities is in line with the usual findings in growth regressions. What follows are the averages of the loading parameters (or error correction coefficients as denoted in the table). Note that these parameters are estimated heterogeneously. The next lines list the estimations of the short-run coefficients which are also averages of individual estimations. The Hausman-test can not reject the hypothesis of poolability of individual coefficients but rejects the hypothesis of joint poolability. The time trend is significant and also population growth is negative and significant just as one would expect from theory.

Table 7 displays the outcomes of the cointegration test of the basic model according to Pedronis (1999) test procedure. ${ }^{38}$

Table 7: Cointegration test of the basic model (Pedroni, 1999)

\begin{tabular}{|l|c|c|}
\cline { 2 - 3 } \multicolumn{1}{c|}{} & Test-statistic & Probability \\
\hline Panel v-stat & 17.87 & 0.99 \\
\hline Panel $\rho$-stat & 0.66 & 0.75 \\
\hline Panel PP-stat & -1.05 & 0.15 \\
\hline Panel ADF-stat & -2.23 & 0.01 \\
\hline \multicolumn{3}{|c|}{} \\
\hline Group $\rho$-stat & 1.32 & 0.91 \\
\hline Group PP-stat & -1.42 & 0.08 \\
\hline Group ADF-stat & -1.14 & 0.13 \\
\hline
\end{tabular}

Time period: 1971 to 2000, Number of cross-sections $=12$, statistics are asymptotically $\mathrm{N}(0,1)$ distributed

The cointegration tests give only limited support of the hypothesis of a long-run relationship. Only the panel ADF-statistics refuses the null hypothesis of no cointegration at a reasonable level of significance. However, Pedroni (2004) shows that the ADF-based tests perform best in small samples, as it is the case here. Therefore, whenever the cointegration tests produce conflicting results, it is advisable to base decision on these outcomes.

\footnotetext{
${ }^{38}$ Pedronis (1999) cointegration analysis was carried out in RATS. This RATSprocedure can be downloaded at www.estima.com
} 


\subsubsection{Estimation results for the augmented models}

In the next steps, this basic empirical growth model is augmented with variables of the data set. In order to keep notation at a moderate level just the PMGE of the long-run relationship, the Hausman-test results and the cointegration test statistics are reported. Table 3A in the appendix presents these findings. The first columns contain the variable identifiers, the coefficient estimates of the PMGE and the respective t-values and the Hausman-test statistics. The last two columns display the Panel ADF-statistics and the Group-ADF-statistics to test for cointegration. Note that these statistics are asymptotically standard normal distributed. The null is no cointegration and is rejected for large negative values of the corresponding statistics.

Before going into detail, the most striking results of table $3 \mathrm{~A}$ in the appendix should be mentioned. The elasticity of output with respect to physical capital investment emerges as relatively robust in the sense that the sign and magnitude of the estimated coefficient of the investment variable does not change considerably when altering the set of explanatory variables. Usually growth regressions are plagued by this phenomenon. ${ }^{39}$ Florax, De Groot and Heijungs (2002) for example carry out a sensitivity analysis to test for robustness of different explanatory variables in growth regressions. According to their findings, the investment in physical capital belongs to one of the few robust determinants. The outcomes of empirical estimations in this paper confirm their results. Also the estimated magnitude of $20-30 \%$ of this elasticity is in line with findings of other surveys. ${ }^{40}$ Relative robustness also applies to the estimated loading parameter (note that averages of these coefficients are displayed in table $3 \mathrm{~A}$ ) which is a measure of the speed of adjustment to equilibrium. According to these estimates, the average speed of equilibrium adjustment is rather fast. The coefficient estimates are in the range of -0.17 to -.50 with the majority of the estimates with a value of around -0.4. These estimates imply that on average the considered countries reduce $40 \%$ of the gap between actual and potential growth in one year once deviated from that path.

From the subject area of fiscal policy, government consumption, the overall tax quota and the tax ratio coefficient appear with a negative sign in the estimations. Cointegration is accepted according to the GroupADF statistic for the specifications that included the tax quota and the tax

\footnotetext{
${ }^{39}$ See Levine and Renelt (1992), Doppelhofer, Miller and Sala-i-Martin (2000) or Bleaney and Nishiyama (2002) for a illustration of these problems

${ }^{40}$ See e.g. Mankiw, Romer and Weil (1992), Islam (1995), Sachverständigenrat (2002) or De la Fuente (2003)
} 
ratio variable. The other specifications do not seem to explain a long-run relationship. The government deficit has a small positive coefficient in contrast to expectations but this estimated equation is not cointegrated.

Inflation and the variation of inflation affect growth negatively with a greater impact of the variation of inflation. However, there are only few signs for cointegration.

The specification including the expenditures of research and development are very likely to be cointegrated. The sign of the estimated R\&D-coefficient is positive although weak in magnitude. Moreover, this coefficient varies considerable according to the implied t-statistic. Note that the number of observations for this estimated equation is limited. Data coverage is from 1981 to 2000 . Interesting is that the magnitude of the human capital coefficient increases compared to the other estimations which cover the full period form 1971 to 2000. The same applies for the specifications including the financial market variables which also cover a shorter period of time. A possible explanation for this finding would be to argue that education has gained importance for economic growth during the last two decades.

Trade openness also affects growth positive but the estimated elasticity is relatively low. The coefficient of the terms of trade variable is negative meaning that countries that export their goods and service relatively expensively compared to the import prices they face do worse in terms of economic growth. This result is not surprising since the terms of trade variable seems to be rather an indicator of international trade competitiveness. A negative coefficient supports the notion that international price competitiveness is important for trade and the overall economy of a country.

Concerning the variables of the subject area of financial markets, only the coefficient of the stock market capitalisation variable has a reasonably high t-value. The magnitude of this coefficient however is limited and the specification does not seem to be cointegrated.

The estimation including the NAWRU as a proxy for labour market rigidities supports the assumption that these rigidities are growthimpeding. Although there is evidence that this relationship is cointegrated.

The estimation results for the demographic variables are hard to interpret. First of all, there are conflicting results of the cointegration tests: One of the panel cointegration tests accepts the null hypothesis of no cointegration in both estimation specifications while the other test 
refuses. Furthermore, the coefficient of the age dependency ratio as well as the coefficient of the population over 65 variable are positive leading to a rather counter-intuitive interpretations. Since there are fundamental problems in observing the impact of aging on economic development in empirical research, one should not focus on these outcomes too much.

The homogeneity hypothesis with regard to the long-run coefficients is accepted for the majority of the estimated equations according to the Hausman-test statistics. A joint rejection for parameter homogeneity was found for the estimations including the overall tax quota, trade openness, credits to the private sector and the NAWRU. Overall, these test outcomes confirm that pooling the coefficients along the long-run dimension seems to be appropriate.

\subsubsection{Estimation results for an overall growth model}

So far isolated effects of different potential growth determinants have been analysed. To get insight into a more comprehensive pattern of growth and its underlying driving forces, an extended growth model was estimated. This model also serves as the starting point for building an indicator of potential growth in the next section. As aforementioned, typically growth regressions are plagued by insufficient parameter robustness. That is, estimated parameters usually change in sign and magnitude when changing one of the three dimensions of the estimation setup: Time period, cross-section and set of explaining variables. Especially when estimating an extended model including many explanatory variables, this issue becomes even more serious since degrees of freedom for estimation are diminishing rapidly.

In order to estimate a suitable overall model of growth based on the data set, the following modus operandi of model selection was carried out. First, the observation period from 1971 to 2000 was chosen for estimation to include as many observations per cross-section as possible. Therefore, some variables of the data set with a lack of observations were excluded due to this restriction. Second, only countries with a full coverage of all variables were considered leading to a total number of cross-sections of 12 (the same as in the estimations above).Third, the basic growth model including investment in physical and human capital and population growth was augmented with variables that had reasonable outcomes in the isolated examination of the previous estimations. The final steps of model selection were based on estimation outcomes of various different estimation setups with a special focus on the outcomes of the Hausman-tests and the Pedroni (1999) cointegration tests. 
Table 8 presents an overall growth model that provides reasonable results with regard to the just mentioned criteria. Besides the familiar proximate determinants of growth this model includes the logarithm of government consumption to GDP, the logarithm of the terms of trade and the logarithm of the NAWRU in the long-run relationship. Furthermore, the standard deviation of inflation enters the underlying panel ECM as exogenous regressor. The investment variable and the human capital variable enter the estimated long-run relationship with positive coefficients, while government consumption, the terms of trade, the noncyclical unemployment rate and the variation of inflation influence longrun growth of GDP per capita negatively. The individual and joint Hausman-tests can not reject the null hypothesis of poolability of the long-run coefficients. Therefore, the notion of common growth factors across industrial countries gets statistical support.

Table 8: PMGE results for an overall growth model

\begin{tabular}{|c|c|c|c|c|c|c|}
\hline \multirow[t]{2}{*}{ Variable } & \multicolumn{3}{|c|}{ Pooled MGE estimates } & \multicolumn{3}{|c|}{ MGE estimates } \\
\hline & Coeff. & Std.Err. & t-ratio & Coeff. & Std.Err. & t-ratio \\
\hline \multicolumn{7}{|c|}{ Long-run coefficients } \\
\hline $\log (\mathrm{sk})$ & 0.165 & 0.033 & 5.022 & -3.378 & 3.429 & -0.985 \\
\hline $\log (\mathrm{sh})$ & 0.051 & 0.028 & 1.797 & -2.770 & 2.968 & -0.933 \\
\hline $\log (\mathrm{cg})$ & -0.571 & 0.058 & -9.826 & 6.787 & 7.317 & 0.928 \\
\hline $\log$ (tot) & -0.078 & 0.013 & -6.150 & 0.966 & 0.992 & 0.973 \\
\hline $\log$ (nawru) & -0.066 & 0.007 & -9.743 & 0.022 & 0.131 & 0.168 \\
\hline & & & & \multicolumn{3}{|c|}{ Joint Hausman test } \\
\hline & \multicolumn{6}{|c|}{ Error correction coefficients } \\
\hline $\log (y(-1))$ & -0.262 & 0.057 & -4.581 & -0.558 & 0.086 & -6.456 \\
\hline \multicolumn{7}{|c|}{ Short-run coefficients } \\
\hline$\Delta \log (\mathrm{sk})$ & 0.095 & 0.035 & 2.754 & 0.028 & 0.034 & 0.814 \\
\hline$\Delta \log (\mathrm{sh})$ & -0.016 & 0.034 & -0.467 & -0.011 & 0.062 & -0.171 \\
\hline$\Delta \log (\mathrm{cg})$ & -0.350 & 0.045 & -7.840 & -0.233 & 0.056 & -4.196 \\
\hline$\Delta \log ($ tot $)$ & 0.000 & 0.017 & -0.001 & -0.001 & 0.022 & -0.060 \\
\hline$\Delta \log ($ nawru) & 0.014 & 0.030 & 0.478 & -0.024 & 0.038 & -0.634 \\
\hline Dummy (91=1) & 0.025 & 0.021 & 1.201 & 0.037 & 0.033 & 1.105 \\
\hline Linear Trend & 0.005 & 0.001 & 3.353 & 0.010 & 0.002 & 5.503 \\
\hline $\mathrm{n}$ & -0.004 & 0.006 & -0.613 & -0.001 & 0.009 & -0.080 \\
\hline isd & -0.210 & 0.121 & -1.737 & -0.201 & 0.161 & -1.249 \\
\hline Intercept & 2.835 & 0.682 & 4.160 & 5.849 & 0.962 & 6.078 \\
\hline
\end{tabular}

Time period: 1971 to 2000 , Number of cross-sections $=12$

Table 8 also shows the estimated coefficients of the short-run component. Note that these are averages of the estimated individual coefficients. 
The next table displays Pedronis' (1999) cointegration test results. The ADF-based test indicate cointegration, all other tests accept the null of no cointegration. Since the ADF-based statistics are most suitable for panels with a limited number of observations, it is fair to assume that the estimated long-run equation characterises a homogenous long-run relationship that is valid for the countries of the cross-section. This model forms the basis for the calculation of the indicators of potential growth that will be described in the next section.

Table 12: Contegration test of the overall growth model

\begin{tabular}{|l|c|c|}
\cline { 2 - 3 } \multicolumn{1}{c|}{} & Test-statistic & Probability \\
\hline Panel v-stat & 12.11 & 0.99 \\
\hline Panel $\rho$-stat & 2.11 & 0.98 \\
\hline Panel PP-stat & -0.81 & 0.21 \\
\hline Panel ADF-stat & -2.97 & 0.00 \\
\hline \multicolumn{2}{|c|}{} \\
\hline Group $\rho$-stat & 2.73 & 0.99 \\
\hline Group PP-stat & -1.47 & 0.07 \\
\hline Group ADF-stat & -2.25 & 0.01 \\
\hline
\end{tabular}

Time period: 1971 to 2000, Number of cross-sections $=12$, statistics are asymptotically $\mathrm{N}(0,1)$ distributed

\section{Indicators of potential growth}

The previous analysis revealed that the observed growth path of the countries can be partly attributed to a set of common growth factors. In this section an alternative calculation of indicators of potential growth derived from the estimations of the overall growth model according to table 8 is presented. Figure $1 \mathrm{~A}$ in the appendix presents the graphs of the actual growth of GDP per capita and the fitted model to gauge how the model behaves when confronted with actual data. Generally, the model fits the data quite well. The exceptions are Japan and the Netherlands for which countries the model seems to systematically underestimate actual growth.

To get an indicator of potential growth, short-run dynamics of the fitted model need to be excluded. Table $4 \mathrm{~A}$ in the appendix displays the mean and standard deviations for the actual data, the fitted model and the fitted model excluding short-run dynamics (or the long-run cointegrated relationship plus the stationary variables). For all countries except Germany, the standard deviation of the fitted model excluding short-run dynamics is lower than the standard deviation of the actual data since 
the more volatile component of the estimated model is left out. ${ }^{41}$ The means of the fitted model excluding short-run dynamics are for most countries less than the actual data. There are basically two reasons for the underestimation of growth of the long-run component of the model: First, the short-run component has a positive mean for most countries leading to a positive impact on growth. Second, growth of GDP per capita is explained by common determinants leaving out country-specific growth factors. Especially, these country-specific growth factors seem to be important for Belgium, Japan, the Netherlands and the United States for which countries the predicted long-run component is very low on average compared to the average actual growth. The United States, for instance, experienced a rapid population growth during the years 1971 to 2000 and a relatively low investment ratio of physical capital compared to the other countries of the sample leading to a low mean value of potential growth according to the empirical model. Clearly, this analysis of potential growth is limited in interpretation since it just accounts for a bounded set of determinants. For example the influence of the information and communication technologies (ICT) on productivity and growth that have recently gained special interest are not considered in this analysis. Furthermore, there are many so called "soft" growth factors like culture, quality of education or social capital that are so hard to incorporate into an econometric approach. ${ }^{42}$ Bearing this caveat in mind, one can nonetheless draw some interesting conclusions on the policy and institutional setting of an economy in order to asses its influence on the aggregate growth of a country.

\section{Conclusion}

In this paper, an alternative for the determination of potential growth of GDP per capita was proposed. This proposal is based on an panel data approach to identify and quantify the effects of common growth factors for a sample of 12 OECD countries. The used data traces back to suggestions and evidence of the theoretical and empirical growth literature. Since the econometric panel approach relies on annual data for the underlying cross-section over a reasonable time span, not all aspects of economic growth can be considered. At least, important growth factors concerning fiscal policy, monetary policy, R\&D, international trade, financial markets, labour markets and demography

\footnotetext{
${ }^{41}$ The reason for the high standard deviation for Germany is that the model overestimates the effect of the German reunification in the year 1991.

${ }^{42}$ For example, see Temple (2001) for the role of education and social capital for growth
} 
were analysed. The econometric approach takes the time-series properties of the data into account. For most of the time-series, individual and panel unit root tests revealed that these series are non-stationary. The identification of non-stationarities is fundamental for the subsequent cointegration framework which was carried out using PSSs (1999) panel ECM estimator and Pedronis' (1999) residual based cointegration test. The identification and quantification of growth factors involved several steps: First, a basic growth model including real GDP per capita, the investment rate in physical capital, human capital and population growth was estimated. The estimated parameters of this model are in line with what one would expect from theory and from other findings of the empirical literature. However, there was limited support of cointegration for this model. In the next step, this basic model was augmented with variables of the data set corresponding to the several subject areas. To get insight into a more comprehensive pattern of growth, an overall growth model including variables that had reasonable outcomes from the preceding isolated estimation, was estimated. This overall model included besides the basic growth factors government consumption, the NAWRU, the terms of trade and the standard deviation of inflation. The Pedroni (1999) test-statistics indicated cointegration for this model. This model also serves as a starting point for the indicators of potential growth. These indicators are calculated by using just the long-run part of the fitted model for each country. When confronted with actual data, these indicators are able to explain growth well for most of the countries. However, for some of the countries, the indicators underestimate the actual growth path. Especially for these countries (Belgium, Japan, the Netherlands and the United States) country-specific factors seemed to play an important role for growth.

There are some refinements and extensions of the econometric estimation that should be accomplished in further analysis. First, a few of the time-series of the data set are subject to breaks. It concerns especially the German data due to the reunification but also some of the human capital data that are based on school enrolment figures for various education levels since definitions of these education levels have changed over time. Taking these data breaks into account will increase the power of unit root tests and would be a natural extension of the analysis. Hassler, Demetrescu and Tarcolea (2004) propose unit root tests for panel data that allow for inclusion of structural breaks. Furthermore, their tests allow for the presence of cross-section dependence which is likely to be the case for the time-series used in this paper. A natural refinement and extension of the cointegration analysis is to test for the number of cointegration vectors à la Johansen (1988). The Pedroni (1999) test assumes that there is just one cointegration 
relationship. If there are more than one cointegration relationships, this needs to be taken into account when estimating panel ECMs. Larsson, Lyhagen and Löthgren (2001) present a test of the cointegration rank based on the mean of the individual rank trace statistics of the Johansen (1988) procedure. Note that this test procedure assumes that the individual model parameters and test statistics are determined independently of each other as Groen and Kleibergen (2003) point out. If this is not the case, they propose a test procedure for determination of the cointegration rank accounting for such cross-section dependencies. 


\section{References}

Aghion, P. and P. Howitt (1992): A Model of Growth through Creative Destruction, Econometrica 60, No. 2, 323-351

Ahn, S. and P. Hemmings (2000): Policy Influences on Economic Growth in OECD Countries: An Evaluation of the Evidence, OECD Economics Working Paper No. 246

Allen, F. and D. Gale (2000): Comparing Financial Systems, MIT Press, Cambridge

Baldwin, R. (2000): Trade and growth: still disagreement about the relationship, OECD Economics Department Working Papers No. 264

Baltagi, B.H. and J.M. Griffin (1997): Pooled estimators vs. their heterogeneous counterparts in the context of dynamic demand for gasoline, Journal of Econometrics Vol. 77, No. 2, 303-327

Barro, R.J. (1997): Determinants of Economic Growth: A Cross-Country Empirical Study, Cambridge, MA, MIT Press

Barro, R.J. and X. Sala-i-Martin (2001): Economic Growth, Third Printing, The MIT Press, Cambridge, MA, London, England

Bassanini, A., S. Scarpetta and P. Hemmings (2001): Economic Growth: The Role of Policies and Institutions. Panel Data Evidence from OECD Countries, OECD Working Paper No. 283

Bleaney, M. and A. Nishiyama (2002): Explaining Growth: A Contest Between Models, Journal of Economic Growth No. 7, 43-56

Coe, D.T. and E. Helpman (1995): International R\&D spillovers, European Economic Review Vol. 39, No. 5, 859-887

De La Fuente, A. (2003): Convergence Equations and Income Dynamics: The Sources of OECD Convergence, 1970-1995, Economica Vol. 70, No. 280, 655-671

De Long, J.B. and L.H. Summers (1991): Equipment Investment and Economic Growth, Quarterly Journal of Economics No. 106:2, 445502 
Dickey, D.A. and W.A. Fuller (1979): Distributions of the estimators for autoregressive time series with a unit root, Journal of the American Statistical Association Vol. 74, No. 366, 427-431

Doppelhofer, G., R.I Miller and X. Sala-i-Martin (2000): Determinants of Long-Term Growth: A Bayesian Averaging of Classical Estimates (BACE) Approach, NBER Working Paper No. 7750

Durlauf, S.N. and D.T. Quah (1999): The New Empirics of Economic Growth, in Handbook of Macroeconomics Vol. 1, Taylor, J.B. and M. Woodford (Editor.), Elsevier

Engel, R.F. and C.W.J. Granger (1987): Co-integration and error correction: representation, estimation and testing, Econometrica Vol. 55 , No. 2, 251-276

Feldstein, M. (1983): Inflation, Tax Rules and Capital Formation, University of Chicago Press, Chicago

Florax, R.J.G.M., H.L.F. De Groot and R. Heijungs (2002): The Empirical Economic Growth Literature, linbergen Institute Discussion Paper $040 / 3$

Fölster, S. and M. Henrekson (2001): Growth Effects of Government Expenditure and Taxation in Rich Countries, European Economic Review Vol. 45, No. 8,1501-1520

Groen, J.J.J. and F. Kleibergen (2003): Likelihood-Based Cointegration Analysis in Panels of Vector Error-Correction Models, Journal of Business \& Economic Statistics, Vol. 21, No. 2

Grossman, G.M. and E. Helpman (1991): Innovation and Growth in the Global Economy, Cambridge, MA, MIT Press

Hadri, K. (2000): Testing for stationarity in heterogeneous panel data, Econometrics Journal Vol. 3, 148-162

Hahn, F.R. (2002): Bedeutung von Aktienmärkten für Wachstum und Wachstumsschwankungen in den OECD-Ländern, Materialien zu Wirtschaft und Gesellschaft Nr. 79, Kammer für Arbeiter und Angestellte für Wien 
Hassler, U., M. Demetrescu and A. Tarcolea (2004): Asymptotically Normal Unit Root Testing: Extensions to Panel Data and Structural Breaks, Goethe University Frankfurt, Discussion Paper

Hausman, J. (1978): Specification tests in econometrics, Econometrica Vol. 46, No. 6, 1251-1271

Im, K.S., M.H. Pesaran and Y. Shin (2002): Testing for Unit Roots in Heterogeneous Panels, DAE Working Papers Amalgamated Series No. 9526, University of Cambridge

Islam, N. (1995): Growth Empirics: A Panel Data Approach, Quarterly Journal of Economics Vol. 110, No. 4, 1127-1170

Johansen, S. (1988): Statistical analysis of cointegrated vectors, Journal of Economic Dynamics and Control No. 12, 231-254

Karlsson, S. and M. Löthgren (2000): On the power and interpretation of panel unit root tests, Economics Letters Vol. 66, 249-256

Larsson, R., J. Lyhagen and M. Löthgren (2001): Likelihood-based cointegration tests in heterogenous panels, Econometrics Journal Vol. 4, 109-142

Levine, R. and D. Renelt (1992): A Sensitivity Analysis of Cross-Country Growth Regressions, The American Economic Review Vol. 82, No. $4,942-963$

Lucas, R.E. Jr. (1988): On the Mechanics of Economic Development, The Journal of Monetary Economics No. 22, 3-42

MacKinnon, J. G. (1996): Numerical Distribution Functions for Unit Root and Cointegration Tests, Journal of Applied Econometrics Vol. 11, No. 6, 601-618.

Mankiw, N. G., D. Romer and D.N. Weil (1992): A Contribution to the Empirics of Economic Growth, Quarterly Journal of Economics Vol. 107, No. 2, 407-37

Milesi-Ferretti, G. and N. Roubini (1998): Growth Effects of Income and Consumption Taxes, Journal of Money, Credit and Banking Vol. 30, No. $4,721-744$ 
Ng, S. and P. Perron (2000): Lag Length selection and the Construction of Unit Root Tests with Good Size and Power, Econometrica Vol. $69,1519-1555$

Padovano, F. and E. Galli (2002): Comparing the growth effects of marginal vs. average tax rates and progressivity, European Journal of Political Economy Vol. 18, No. 3, 529-544

Pagano, M. (1993): Financial Markets and Growth: An Overview, European Economic Review Vol. 37, No. 2/3, 613-622.

Pedroni, P. (1999): Critical Values for Cointegration Tests in Heterogeneous Panels with Multiple Regressors, Oxford Bulletin of Economics and Statistics, Special Issue, Vol. 61, No. 4, 653-670

Pedroni, P. (2004): Panel Cointegration: Asymptotic And Finite Sample Properties of Pooled Time Series Tests With an Application to the PPP Hypothesis, Econometric Theory Vol. 20, No. 3, 597-626

Pesaran, M.H., Y. Shin and R.P. Smith (1999): Pooled Mean Group Estimation of Dynamic Heterogeneous Panels, Journal of the American Statistical Association Vol. 94, No. 446, 621-634

Phillips, P.C.B. and P. Perron (1988): Testing for a unit root in time series regression, Biometrika No. 75, 335-346

Quah, D. (1993): Empirical cross-section dynamics in economic growth, European Economic Review Vol. 37, No. 2/3, 426-434

Romer, P.M. (1986): Increasing Returns and Long-Run Growth, The Journal of Political Economy Vol. 94, No. 5, 1002-1037

Sachverständigenrat zur Begutachtung der gesamtwirtschaftlichen Entwicklung (2002): Zwanzig Punkte für Beschäftigung und Wachstum 2002/2003, Stuttgart

Siebert, H. (2002): Economic Policy for Aging Societies, Springer-Verlag Berlin, Heidelberg

Solow, R.M. (1956): A Contribution to the Theory of Economic Growth, Quarterly Journal of Economics Vol. 70, No. 1, 65-94 
Stockman, A.C. (1981): Anticipated inflation and the capital stock in a cash-in-advance economy, Journal of Monetary Economics Vol. 8, No. 3, 387-393

Teles, V.K. (2004): The Role of Human Capital in Economic Growth, University of Brasilia, Department of Economics Working Paper

Temple, J. (1999): The New Growth Evidence, Journal of Economic Literature Vol. 37, No. 1, 112-56

Temple, J. (2000): Inflation and growth: stories short and tall, Journal of economic surveys Vol. 14, No. 4, 395-426

Temple, J. (2001): Growth Effects of Education and Social Capital in the OECD Countries, CEPR Discussion Paper No. 2875

Tobin, J. (1965): Money and economic growth, Econometrica 33, 671684

Widmalm, F. (2001): Tax Structure and Growth: Are Some Taxes Better than Others?, Public Choice No. 107, 199-219 


\section{Appendix}

\section{Table 1A: Description of data}

\begin{tabular}{|c|c|c|c|}
\hline Dependent variable & Coverage & $\begin{array}{c}\text { No. of } \\
\text { cross- } \\
\text { sections }\end{array}$ & Identifier \\
\hline Real GDP per capita $^{1}$ & $1970-2000$ & 23 & $y$ \\
\hline
\end{tabular}

Variables of the basic model

\begin{tabular}{|l|c|c|c|}
\hline Investment/GDP (public + private) $^{1}$ & $1970-2000$ & 23 & sk \\
\hline $\begin{array}{l}\text { Investment in human capital (Number of } \\
\text { person enrolled in secondary and tertiary } \\
\text { education/Total population) }^{3}\end{array}$ & $1970-2000$ & 23 & sh \\
\hline Population growth $^{1}$ & $1970-2000$ & 23 & $\mathrm{n}$ \\
\hline
\end{tabular}

\begin{tabular}{|c|c|c|c|}
\hline \multicolumn{4}{|l|}{ Fiscal policy } \\
\hline Government consumption/GDP ${ }^{1}$ & $1970-2000$ & 23 & $\mathrm{cg}$ \\
\hline $\begin{array}{l}\text { Tax quota (Indirect taxes }+ \text { direct taxes + } \\
\text { social contributions/GDP) }{ }^{1}\end{array}$ & $1970-2000$ & 12 & $\operatorname{taxq}$ \\
\hline Direct taxes/GDP ${ }^{1}$ & $1970-2000$ & 12 & ty \\
\hline Indirect taxes/GDP ${ }^{1}$ & $1970-2000$ & 12 & tind \\
\hline Indirect/Direct taxes ${ }^{1}$ & $1970-2000$ & 12 & $\operatorname{tr}$ \\
\hline Public deficit $^{1}$ & $1970-2000$ & 12 & nlgq \\
\hline
\end{tabular}

\begin{tabular}{|l|c|c|c|}
\hline Monetary policy \\
\hline Inflation (consumer prices) $^{1}$ & $1970-2000$ & 23 & i \\
\hline $\begin{array}{l}\text { Standard deviation of inflation (past three } \\
\text { years) }\end{array}$ & $1970-2000$ & 23 & isd \\
\hline
\end{tabular}

Research and development

Expenditure on research and development/GDP (public + private) ${ }^{1}$

\begin{tabular}{|c|c|c|c|}
\hline \multirow{2}{*}{\begin{tabular}{|l|} 
International trade \\
$\underset{1}{\text { Trade openness/GDP (imports + exports/GDP) }}$ \\
\end{tabular}} & \multirow[b]{2}{*}{$1970-2000$} & \multirow[b]{2}{*}{23} & \multirow[b]{2}{*}{ off } \\
\hline & & & \\
\hline Terms of Trade (export prices/import prices) ${ }^{1}$ & $1970-2000$ & 12 & tot \\
\hline
\end{tabular}




\section{Table 1A continued}

\begin{tabular}{|c|c|c|c|}
\hline & Coverage & $\begin{array}{c}\text { No. of } \\
\text { cross- } \\
\text { sections }\end{array}$ & Identifier \\
\hline \multicolumn{4}{|l|}{ Financial markets } \\
\hline Stock market capitalisation/GDP ${ }^{2}$ & $1976-2000$ & 16 & cap \\
\hline Stocks traded/GDP ${ }^{2}$ & $1976-2000$ & 16 & tvt \\
\hline $\begin{array}{l}\text { Turnover ratio (stocks traded/ stock market } \\
\text { capitalisation) } 2\end{array}$ & $1976-2000$ & 16 & turn \\
\hline Credits to private sector/GDP ${ }^{4}$ & $1970-2000$ & 21 & credit \\
\hline \multicolumn{4}{|l|}{ Labour markets } \\
\hline $\begin{array}{l}\text { NAWRU (measure of non-cyclical } \\
\text { unemployment rate) }{ }^{1}\end{array}$ & $1970-2000$ & 12 & nawru \\
\hline
\end{tabular}

\section{Demography}

\begin{tabular}{|l|c|c|c|}
\hline $\begin{array}{l}\text { Age dependency (persons over 65 years/ } \\
\text { persons of age } 15 \text { to } 64 \text { years) }\end{array}$ & $1971-2000$ & 12 & adr \\
\hline Population over 65/total population $^{2}$ & $1970-2000$ & 12 & pop65 \\
\hline
\end{tabular}

\section{Sources:}

1: OECD Economic Outlook, various editions

2: World Development Indicators of the World Bank

3: Education Database of the UNESCO

4: International Financial Statistics of the IMF

Cross section (see number of cross-sections above):

\section{3}

Austria, Australia, Belgium, Switzerland, Germany, Denmark, Spain, France, United Kingdom, Greece, Ireland, Iceland, Italy, Japan, South-Korea, Luxembourg, Netherlands, Norway, New Zealand, Portugal, Sweden, Turkey, USA

\section{1}

Austria, Australia, Belgium, Switzerland, Germany, Denmark, Spain, France, United Kingdom, Greece, Ireland, Italy, Japan, South-Korea, Luxembourg, Netherlands, Norway, New Zealand, Portugal, Sweden, USA

\section{6}

Austria, Australia, Belgium, Switzerland, Germany, Denmark, Spain, France, United Kingdom, Greece, Italy, Japan, South-Korea, Netherlands, Sweden, USA

12

Austria, Belgium, Germany, Denmark, France, United Kingdom, Italy, Japan, Netherlands, Norway, Sweden, USA 
Table 2A: Summary of panel unit root tests:

\begin{tabular}{|l|c|c|c|}
\hline Variable & $\begin{array}{c}\text { Cross- } \\
\text { sections }\end{array}$ & Level & $\begin{array}{c}\text { First } \\
\text { difference }\end{array}$ \\
\hline GDP per total employment, log & 23 & $\mathrm{I}(1)$ & $\mathrm{I}(0)$ \\
\hline Investment ratio, log & 23 & $\mathrm{I}(1)$ & $\mathrm{I}(0)$ \\
\hline Human capital investment, log & 23 & $\mathrm{I}(1)$ & $\mathrm{I}(0)$ \\
\hline Population growth & 23 & $\mathrm{I}(0)$ & - \\
\hline R\&D expenditure (\% of GDP), log & 20 & $\mathrm{I}(1)$ & $\mathrm{I}(0)$ \\
\hline $\begin{array}{l}\text { Inflation (deflator for private } \\
\text { consumption) }\end{array}$ & 23 & $\mathrm{I}(1)$ & $\mathrm{I}(0)$ \\
\hline Standard deviation of inflation & 23 & $\mathrm{I}(0)$ & - \\
\hline $\begin{array}{l}\text { Real government consumption } \\
\text { (\% of GDP),log }\end{array}$ & 23 & $\mathrm{I}(1)$ & $\mathrm{I}(0)$ \\
\hline $\begin{array}{l}\text { Tax ratio (direct/indirect taxes), } \\
\text { log }\end{array}$ & 16 & $\mathrm{I}(1)$ & $\mathrm{I}(0)$ \\
\hline $\begin{array}{l}\text { Openness (imports + } \\
\text { exports/GDP), log }\end{array}$ & 23 & $\mathrm{I}(1)$ & $\mathrm{I}(0)$ \\
\hline $\begin{array}{l}\text { Stock market capitalisation (\% of } \\
\text { GDP), log }\end{array}$ & 16 & $\mathrm{I}(1)$ & $\mathrm{I}(0)$ \\
\hline $\begin{array}{l}\text { Claims on private sector (\% of } \\
\text { GDP), log }\end{array}$ & 21 & $\mathrm{I}(1)$ & $\mathrm{I}(0)$ \\
\hline Stocks traded (\% of GDP), log & 23 & $\mathrm{I}(1)$ & $\mathrm{I}(0)$ \\
\hline $\begin{array}{l}\text { Turnover ratio (stocks } \\
\text { traded/market capitalisation), log }\end{array}$ & 23 & $\mathrm{I}(1)$ & $\mathrm{I}(0)$ \\
\hline $\begin{array}{l}\text { Net lending government (\% of } \\
\text { GDP) }\end{array}$ & 12 & $\mathrm{I}(1)$ & $\mathrm{I}(0)$ \\
\hline NAWRU, log & 12 & $\mathrm{I}(1)$ & $\mathrm{I}(0)$ \\
\hline Overall tax quota, log & 12 & $\mathrm{I}(1)$ & $\mathrm{I}(0)$ \\
\hline Direct taxes (\% of GDP), log & $\mathrm{I}(1)$ & $\mathrm{I}(0)$ \\
\hline Indirect taxes (\% of GDP), log & 12 & $\mathrm{I}(1)$ & $\mathrm{I}(0)$ \\
\hline Terms of trade, log & $\mathrm{I}(2)$ & $\mathrm{I}(1)$ \\
\hline Age dependency ratio, log \\
\hline $\begin{array}{l}\text { Population over 65 (\% of total } \\
\text { aopulation), log }\end{array}$ & $\mathrm{I}(1)$ & $\mathrm{I}(0)$ \\
\hline aria I $)$ & - \\
\hline
\end{tabular}

I(1): Variable is integrated of order 1

$\mathrm{I}(0)$ : Variable is stationary 
Table 3A: Augmented growth models

\begin{tabular}{|c|c|c|c|c|c|c|}
\hline $\begin{array}{c}\text { Explanatory } \\
\text { variable }\end{array}$ & PMGE* & $\begin{array}{c}\text { Hausman- } \\
\text { test }^{\star \star}\end{array}$ & \begin{tabular}{|c|} 
Joint \\
Hausman- \\
test**
\end{tabular} & $\begin{array}{l}\text { Loading } \\
\text { parameter* }\end{array}$ & $\begin{array}{l}\text { Panel- } \\
\text { ADF*** }\end{array}$ & 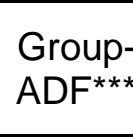 \\
\hline \multicolumn{7}{|l|}{ Fiscal policy } \\
\hline $\begin{array}{l}\text { Isk } \\
\text { Ish } \\
n \\
\text { Icg }\end{array}$ & \begin{tabular}{|c|}
$0.147(3.249)$ \\
$0.074(2.390$ \\
$-0.005(-0.886)$ \\
$-1.163(-15.833)$
\end{tabular} & \begin{tabular}{|l|}
$1.08(0.30)$ \\
$0.86(0.35)$ \\
$0.08(0.78)$
\end{tabular} & $3.39(0.34)$ & $-0.169(-4.138)$ & -1.083 & -0.456 \\
\hline $\begin{array}{l}\text { Isk } \\
\text { Ish } \\
n \\
\text { Itaxq }\end{array}$ & $\begin{array}{c}0.392(16.483) \\
0.090(4.759) \\
0.007(0.464) \\
-0.460(-9.568)\end{array}$ & \begin{tabular}{|l|}
$2.93(0.09)$ \\
$0.09(0.77)$ \\
\\
$4.30(0.04)$
\end{tabular} & $9.15(0.03)$ & $-0.449(-3.912)$ & -1.031 & -2.601 \\
\hline $\begin{array}{l}\text { Isk } \\
\text { Ish } \\
n \\
\text { Itr }\end{array}$ & $\begin{array}{c}0.267(13.028) \\
0.218(7.497) \\
-0.012(-1.094) \\
-0.028(-1.896)\end{array}$ & $\begin{array}{l}0.31(0.58) \\
0.89(0.35) \\
0.20(0.65)\end{array}$ & $3.84(0.28)$ & $-0.456(-3.709)$ & -1.954 & -2.835 \\
\hline $\begin{array}{l}\text { Isk } \\
\text { Ish } \\
n \\
\text { nlgq }\end{array}$ & $\begin{array}{c}0.178(7.962) \\
0.115(4.861) \\
-0.010(-1.591) \\
0.002(2.758)\end{array}$ & $\begin{array}{l}0.92(0.34) \\
3.33(0.07) \\
1.27(0.26)\end{array}$ & $4.07(0.25)$ & $-0.483(-3.962)$ & -0.505 & 0.566 \\
\hline \multicolumn{7}{|c|}{ Monetary policy } \\
\hline $\begin{array}{l}\text { Isk } \\
\text { Ish } \\
\mathrm{n} \\
\mathrm{i}\end{array}$ & $\begin{array}{c}0.367(0.030) \\
0.167(4.724) \\
-0.007(-1.263) \\
-0.153(-1.289)\end{array}$ & \begin{tabular}{|l|}
$0.41(0.52)$ \\
$0.03(0.86)$
\end{tabular} & $0.45(0.80)$ & $-0.411(-3.437)$ & -1.997 & -1.761 \\
\hline $\begin{array}{l}\text { Isk } \\
\text { Ish } \\
n \\
\text { isd }\end{array}$ & $\begin{array}{c}0.217(10.830) \\
0.306(9.643) \\
-0.011(-1.967) \\
-0.683(-2.480)\end{array}$ & 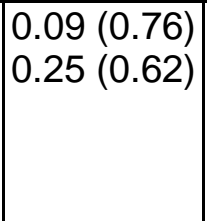 & $0.41(0.81)$ & $-0.393(-3.423)$ & -0.372 & 0.240 \\
\hline \multicolumn{7}{|c|}{ Research and development } \\
\hline $\begin{array}{l}\text { Isk } \\
\text { Ish } \\
\text { In } \\
\text { Ird }\end{array}$ & $\begin{array}{c}0.266(21.875) \\
0.729(12.444) \\
-0.011(-1.111) \\
0.040(1.050)\end{array}$ & $\begin{array}{l}2.05(0.15) \\
0.75(0.39) \\
0.47(0.49)\end{array}$ & $2.22(0.53)$ & $-0.487(-2.541)$ & -4.444 & -3.416 \\
\hline \multicolumn{7}{|c|}{ International trade } \\
\hline $\begin{array}{c}\text { Isk } \\
\text { Ish } \\
n \\
\text { Ioff }\end{array}$ & $\begin{array}{c}0.140(6.903) \\
0.329(8.706) \\
-0.013(-2.597) \\
0.016(0.537)\end{array}$ & \begin{tabular}{|l|}
$5.59(0.02)$ \\
$5.13(0.02)$ \\
$0.38(0.54)$
\end{tabular} & $12.36(0.01)$ & $-0.287(-2.490)$ & -3.649 & -2.670 \\
\hline
\end{tabular}


Table 3A continued

\begin{tabular}{|c|c|c|c|c|c|c|}
\hline $\begin{array}{c}\text { Explanatory } \\
\text { variable }\end{array}$ & PMGE* & $\begin{array}{c}\text { Hausman- } \\
\text { test }^{\star \star}\end{array}$ & $\begin{array}{c}\text { Joint } \\
\text { Hausman- } \\
\text { test** }\end{array}$ & $\begin{array}{l}\text { Loading } \\
\text { parameter* }\end{array}$ & $\begin{array}{l}\text { Panel- } \\
\text { ADF }^{\star \star \star}\end{array}$ & $\begin{array}{l}\text { Group- } \\
\text { ADF*** }\end{array}$ \\
\hline $\begin{array}{l}\text { Isk } \\
\text { Ish } \\
\text { n } \\
\text { Itot }\end{array}$ & $\begin{array}{c}0.210(13.081) \\
0.231(8.149) \\
-0.016(-1.974) \\
-0.064(-2.392)\end{array}$ & $\begin{array}{l}1.46(0.23) \\
1.70(0.19)\end{array}$ & $4.68(0.20)$ & $-0.411(-3.437)$ & -1.997 & -1.761 \\
\hline
\end{tabular}

\section{Financial markets}

\begin{tabular}{|c|c|c|c|c|c|c|}
\hline $\begin{array}{l}\text { Isk } \\
\text { Ish } \\
\text { n } \\
\text { Icap }\end{array}$ & $\begin{array}{l}0.371(16.585) \\
0.168(5.875) \\
0.000(0.008) \\
0.023(4.273)\end{array}$ & $\begin{array}{l}1.05(0.31) \\
0.58(0.45) \\
\\
1.03(0.31)\end{array}$ & $1.17(0.76)$ & $-0.490(-4.269)$ & 1.453 & -0.1222 \\
\hline $\begin{array}{l}\text { Isk } \\
\text { Ish } \\
n \\
\text { Itvt }\end{array}$ & $\begin{array}{c}0.204(10.769) \\
0.591(9.537) \\
-0.016(-4.455) \\
0.001(0.437)\end{array}$ & $\begin{array}{l}0.10(0.75) \\
0.11(0.75) \\
0.00(0.99)\end{array}$ & $1.28(0.73)$ & $-0.215(-1.881)$ & 0.275 & 0.059 \\
\hline $\begin{array}{l}\text { Isk } \\
\text { Ish } \\
\text { n } \\
\text { Iturn }\end{array}$ & $\begin{array}{c}0.511(15.888) \\
0.158(5.579) \\
-0.001(-0.111) \\
0.002(0.516)\end{array}$ & $\begin{array}{l}5.87(0.02) \\
0.25(0.62) \\
0.00(0.97)\end{array}$ & $5.94(0.11)$ & $-0.409(-4.227)$ & 0.904 & 1.021 \\
\hline $\begin{array}{c}\text { Isk } \\
\text { Ish } \\
n \\
\text { Icredit }\end{array}$ & $\begin{array}{l}0.222(12.497) \\
0.937(11.281) \\
-0.020(-4.045) \\
-0.002(-0.466)\end{array}$ & $\begin{array}{l}0.16(0.69) \\
0.24(0.62) \\
\\
1.00(0.32)\end{array}$ & $15.68(0.00)$ & $-0.197(-1.515)$ & 1.108 & -0.073 \\
\hline \multicolumn{7}{|c|}{ Labour markets } \\
\hline $\begin{array}{c}\text { Isk } \\
\text { Ish } \\
n \\
\text { Inawru }\end{array}$ & \begin{tabular}{|c|}
$0.187(10.738)$ \\
$-0.113(-6.632)$ \\
$-0.012(-1.692)$ \\
$-0.106(-19.256)$
\end{tabular} & $\begin{array}{l}0.15(0.70) \\
6.09(0.01) \\
1.08(0.30)\end{array}$ & $11.37(0.01)$ & $-0.492(-3.921)$ & -2.932 & -1.818 \\
\hline \multicolumn{7}{|c|}{ Demography } \\
\hline $\begin{array}{l}\text { Isk } \\
\text { Ish } \\
n \\
\text { ladr }\end{array}$ & $\begin{array}{c}0.181(6.772) \\
-0.103(-3.625) \\
-0.005(-0.933) \\
0.204(2.197)\end{array}$ & $\begin{array}{l}1.91(0.17) \\
0.24(0.63)\end{array}$ & $2.86(0.24)$ & $-0.501(-4.614)$ & -2.545 & -1.780 \\
\hline $\begin{array}{c}\text { Isk } \\
\text { Ish } \\
n \\
\text { dlpop65 }\end{array}$ & $\begin{array}{c}0.150(10.169) \\
0.090(4.747) \\
-0.001(-0.088) \\
0.022(10.309)\end{array}$ & $\begin{array}{l}0.58(0.45) \\
0.20(0.65) \\
\\
2.14(0.14)\end{array}$ & $2.91(0.41)$ & $-0.491(-3.825)$ & -0.542 & -2.733 \\
\hline
\end{tabular}

*: t-values in brackets, **: p-values in brackets, $* \star *$ : test-statistic is standard normal The prefix "l" denotes logarithm, consult table $1 \mathrm{~A}$ for variable identifiers The cross-section of all estimations covers 12 countries (see table $1 \mathrm{~A}$ for detailed data coverage)

A constant, a time trend and a Dummy (1990=1, 0 else) for German unification are included in all specifications, for stationary variables no Hausman-test statistic was calculated 
Figure 1A: Observed and fitted annual growth rates of GDP per capita, 1971-2000

Austria

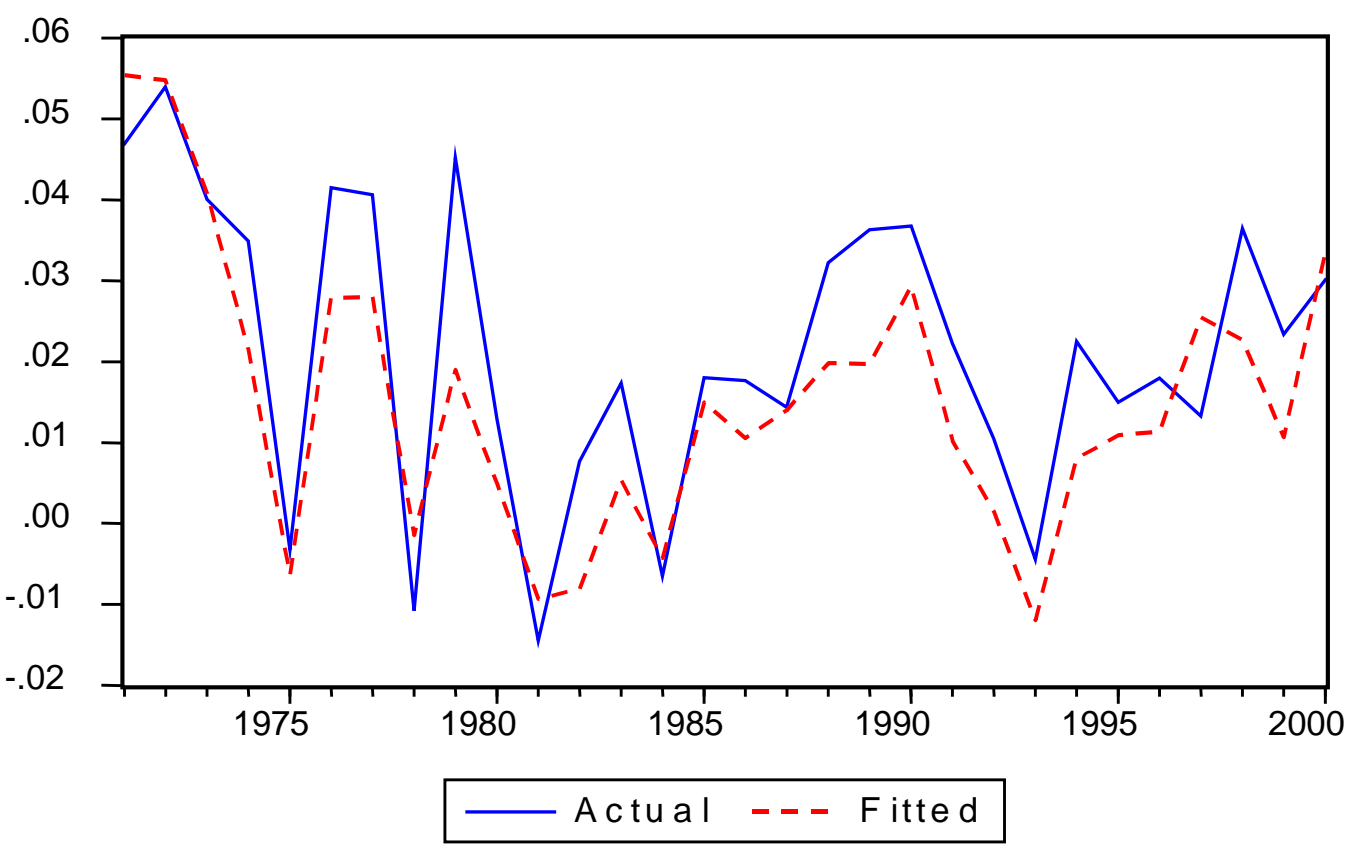

Belgium

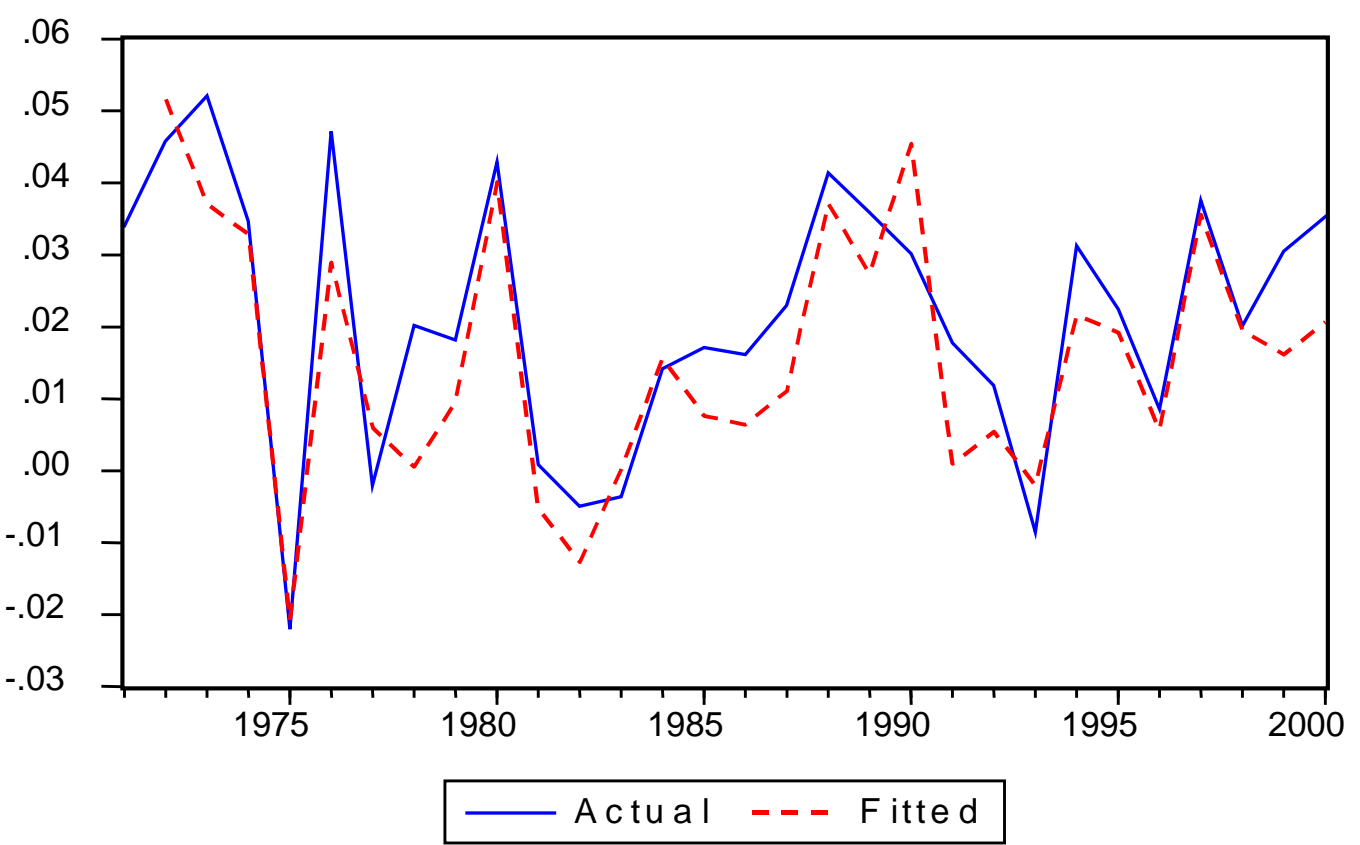


Figure 1A continued

Germany

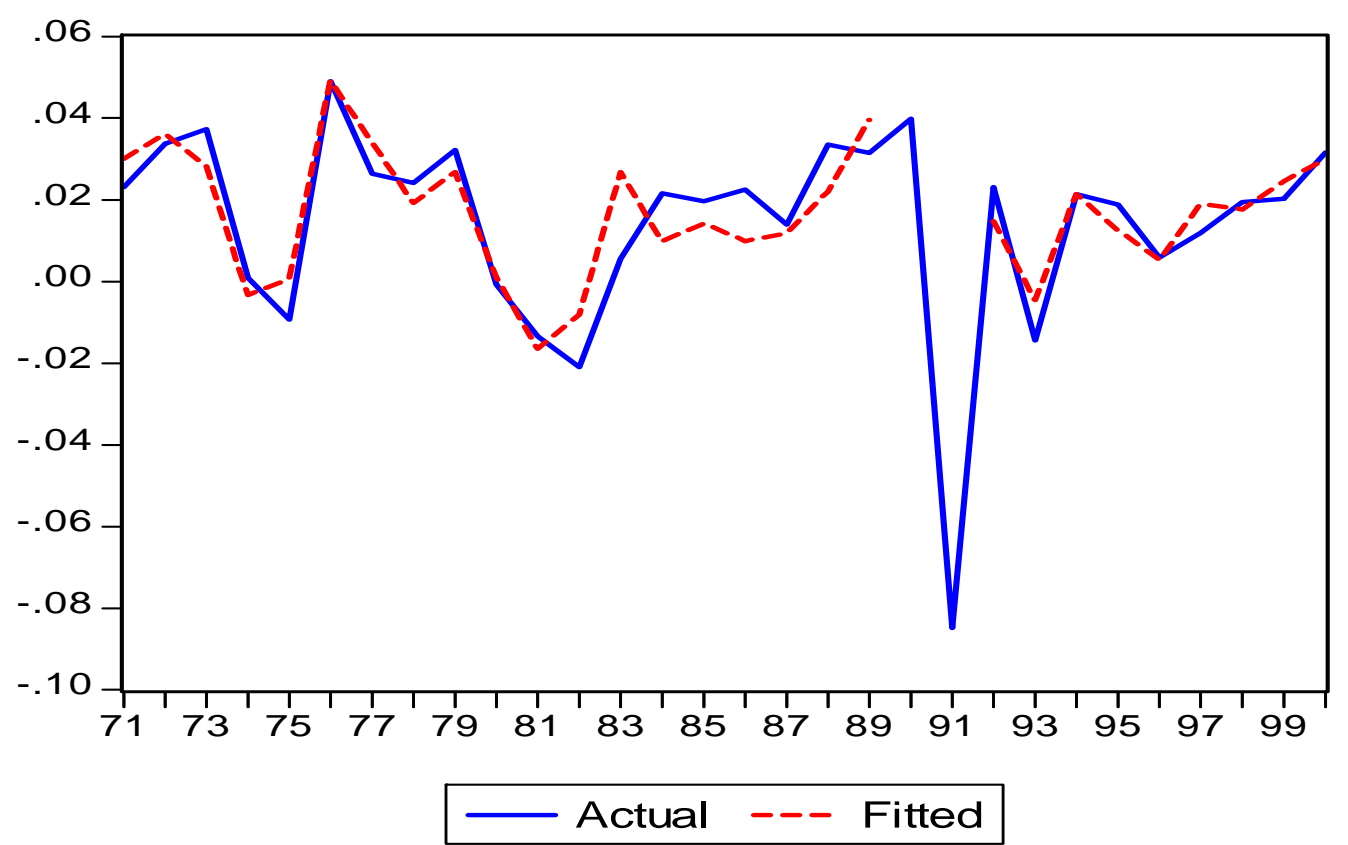

Denmark

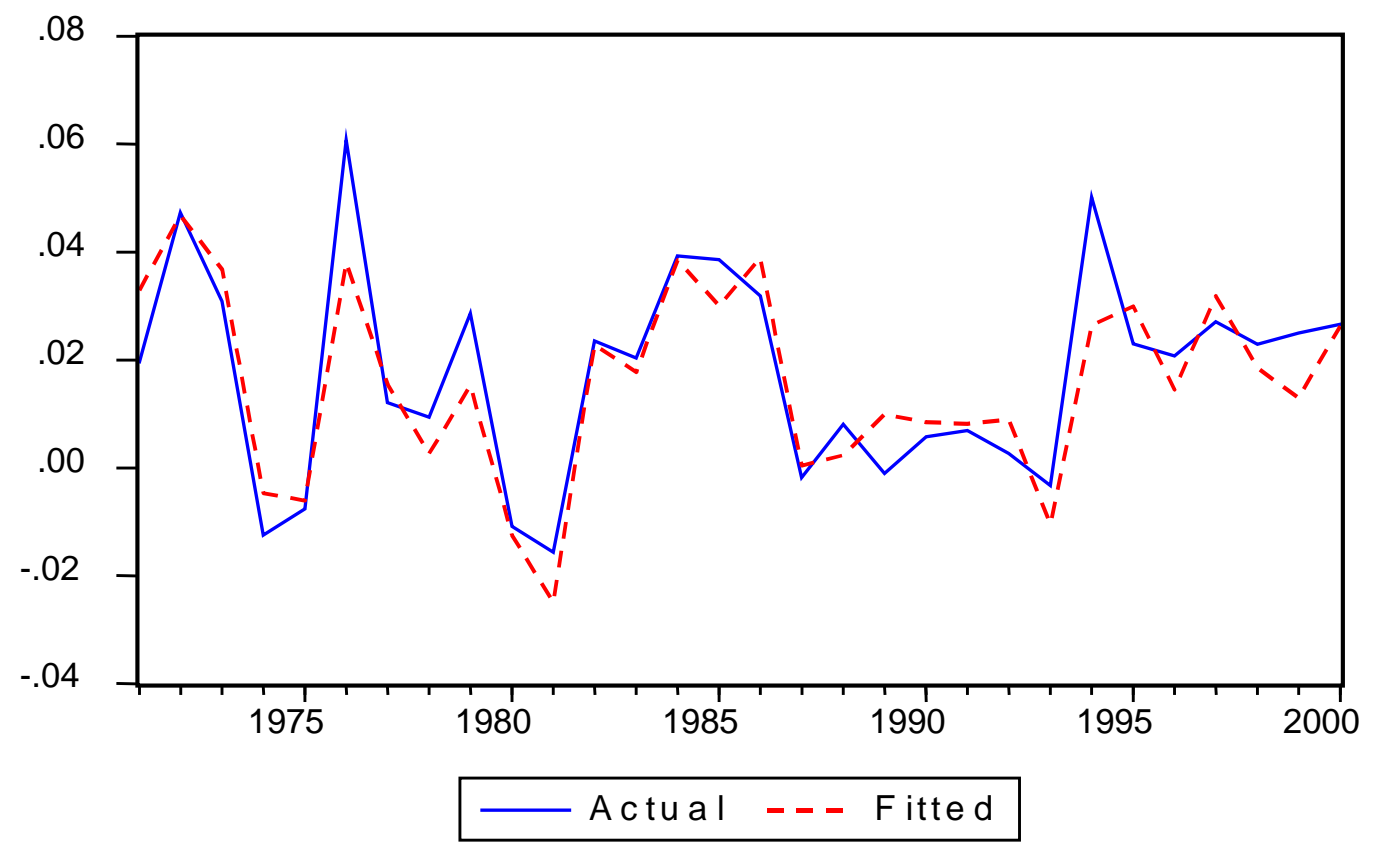


Figure 1A continued

\section{France}

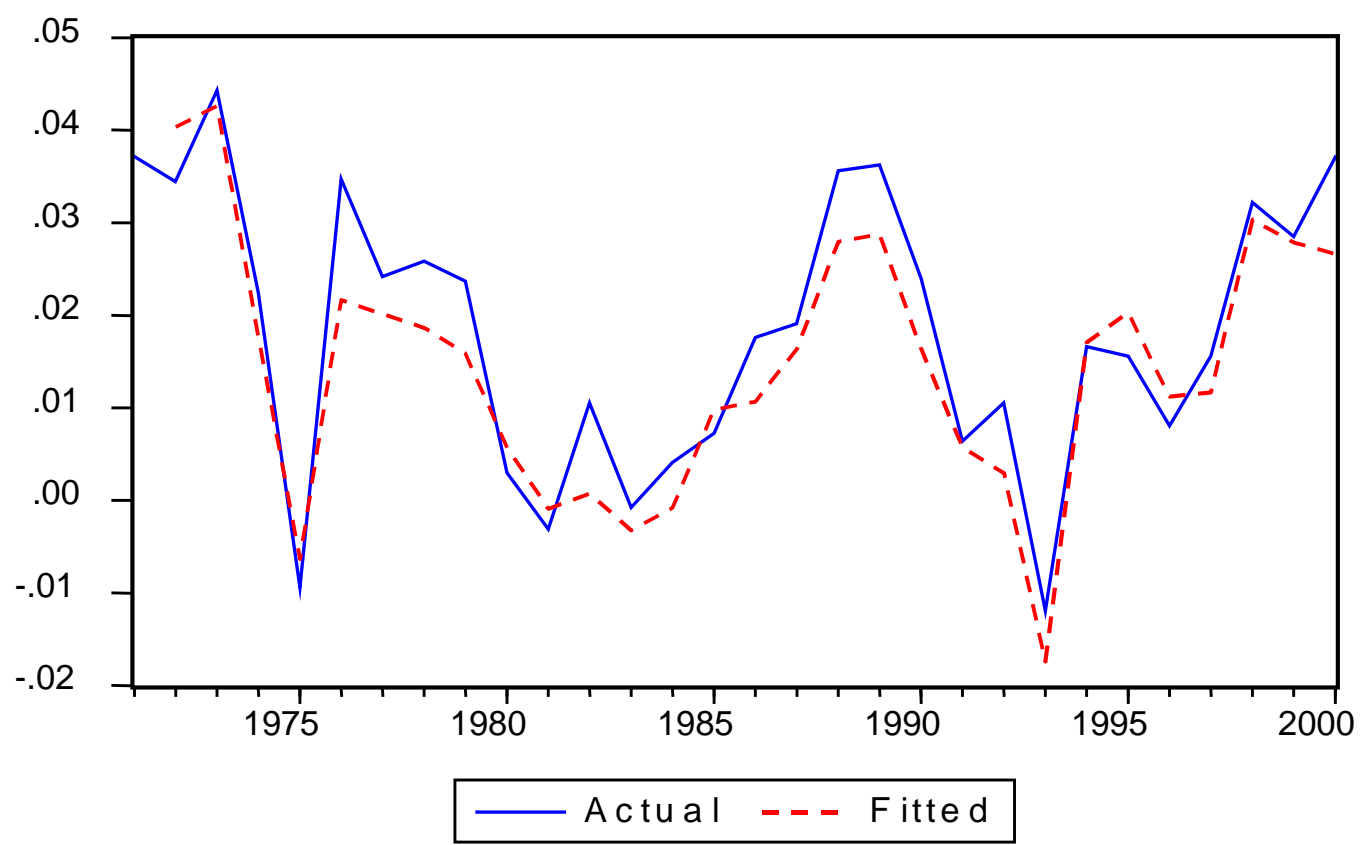

United Kingdom

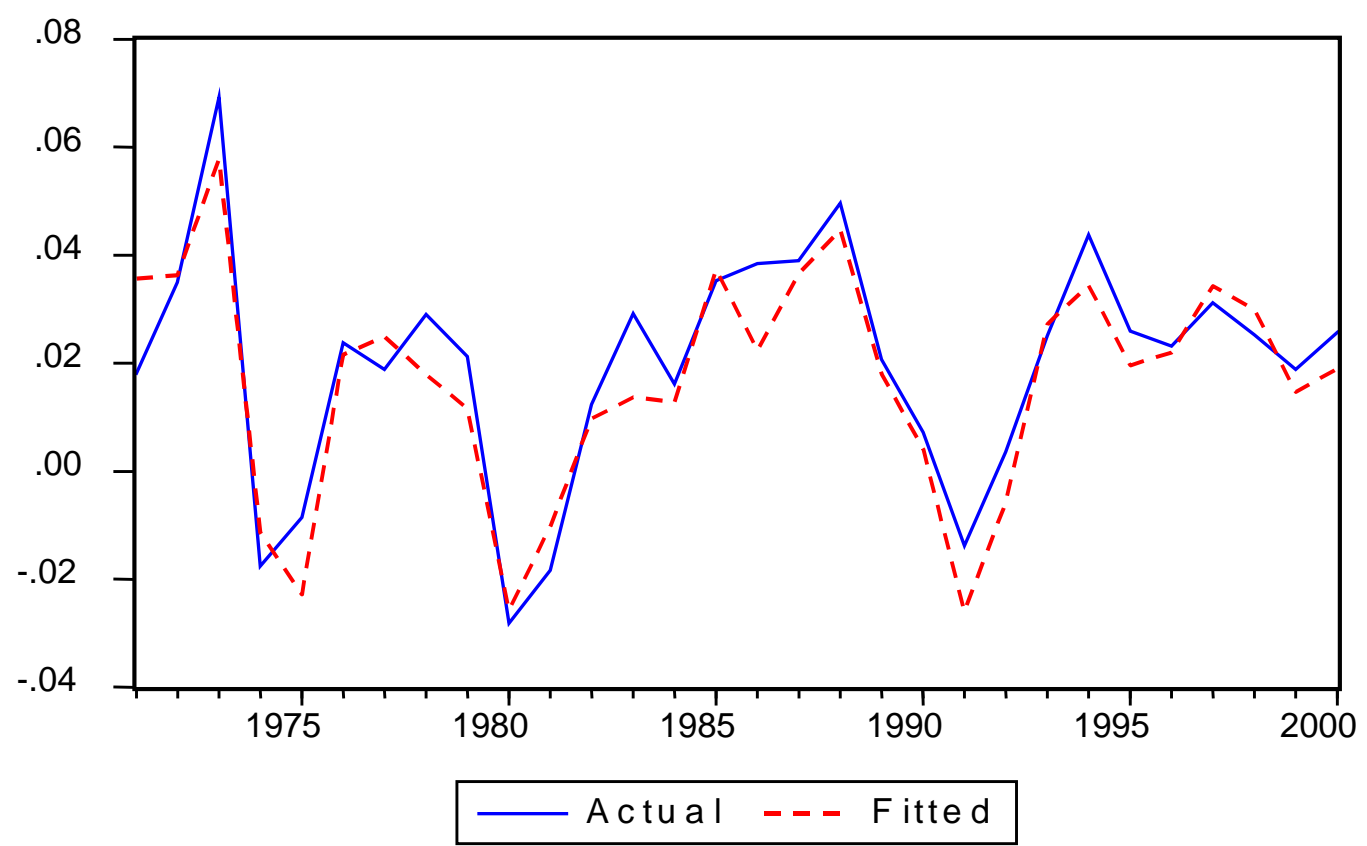


Figure 1A continued

Italy

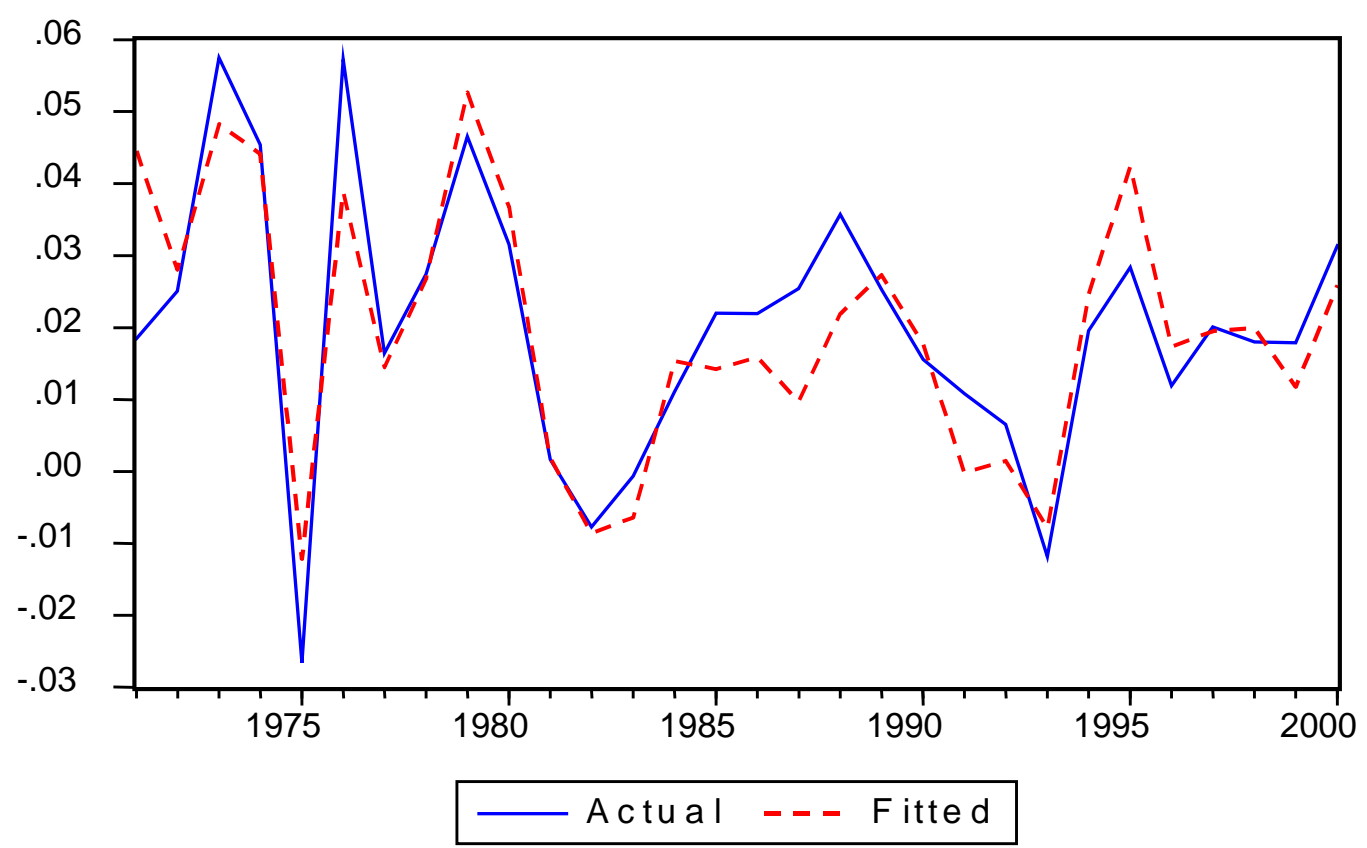

Japan

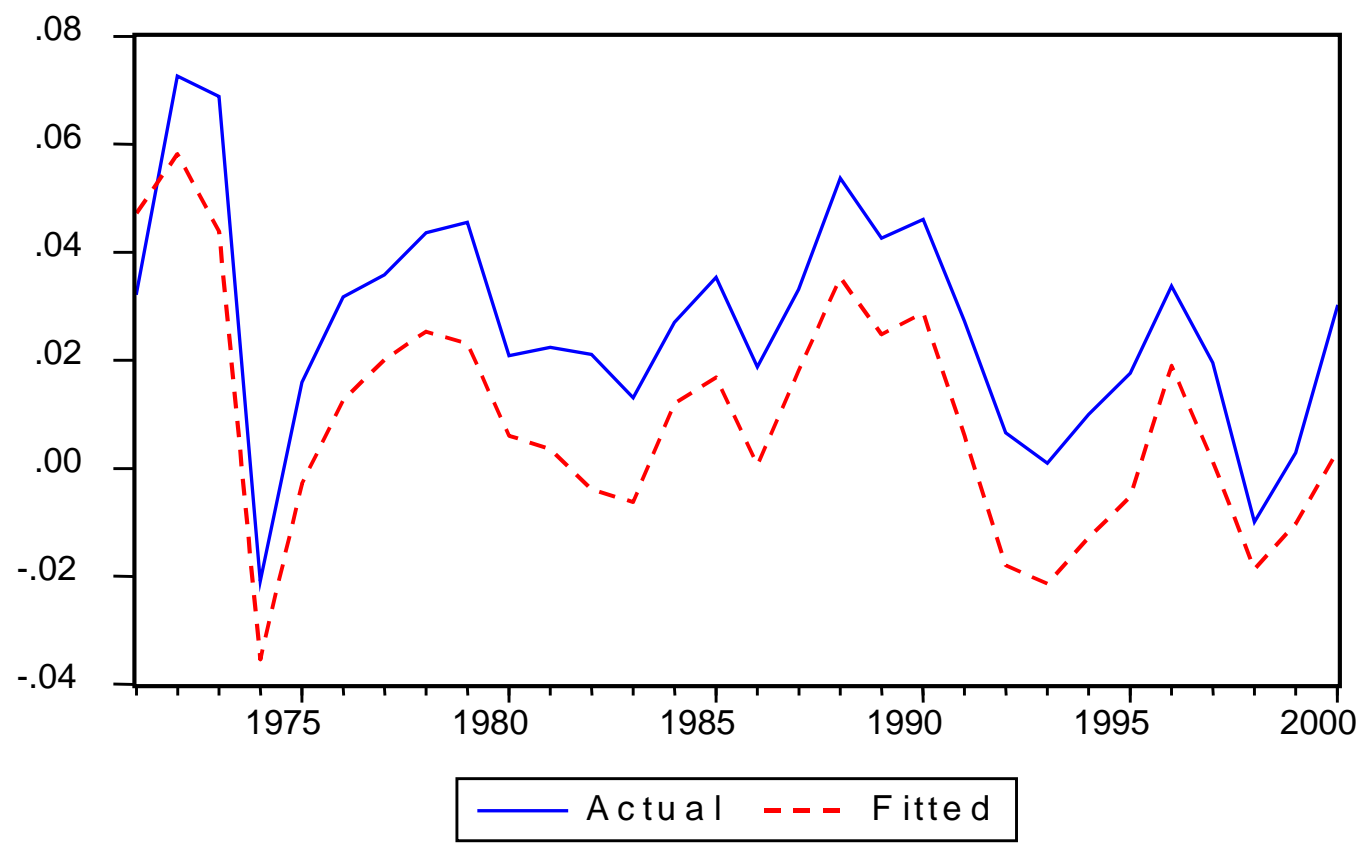


Figure 1A continued

Netherlands

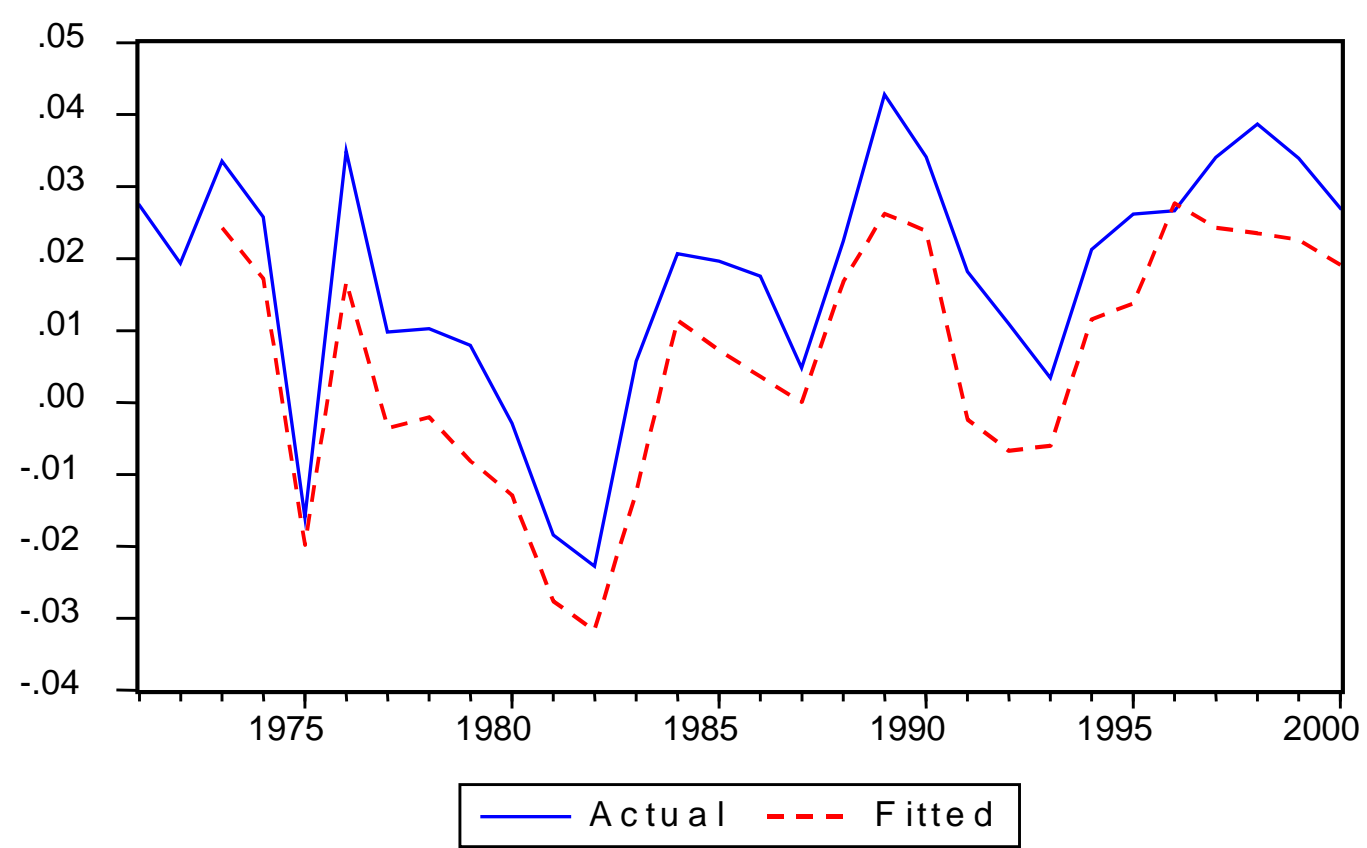

Norway

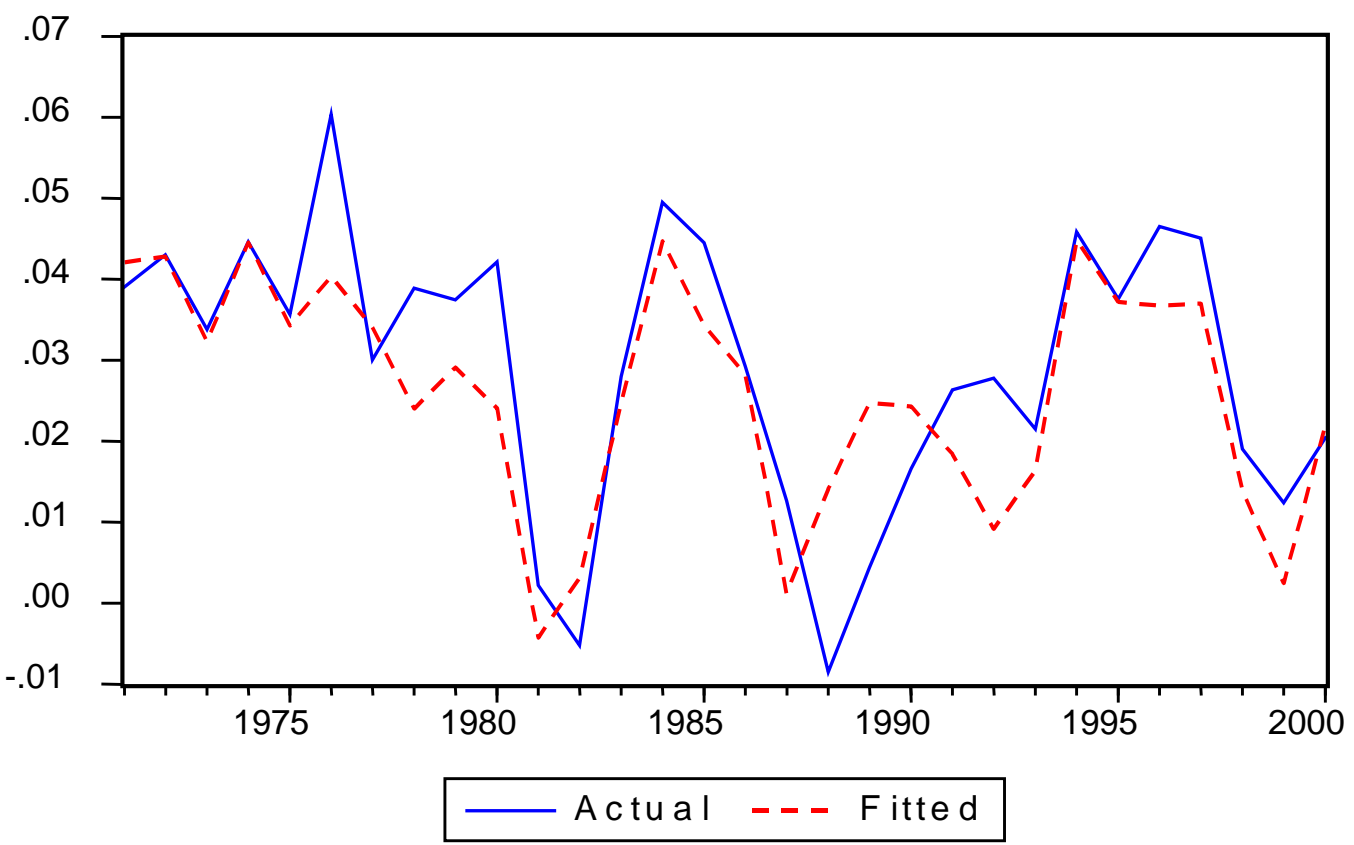


Figure 1A continued

\section{Sweden}

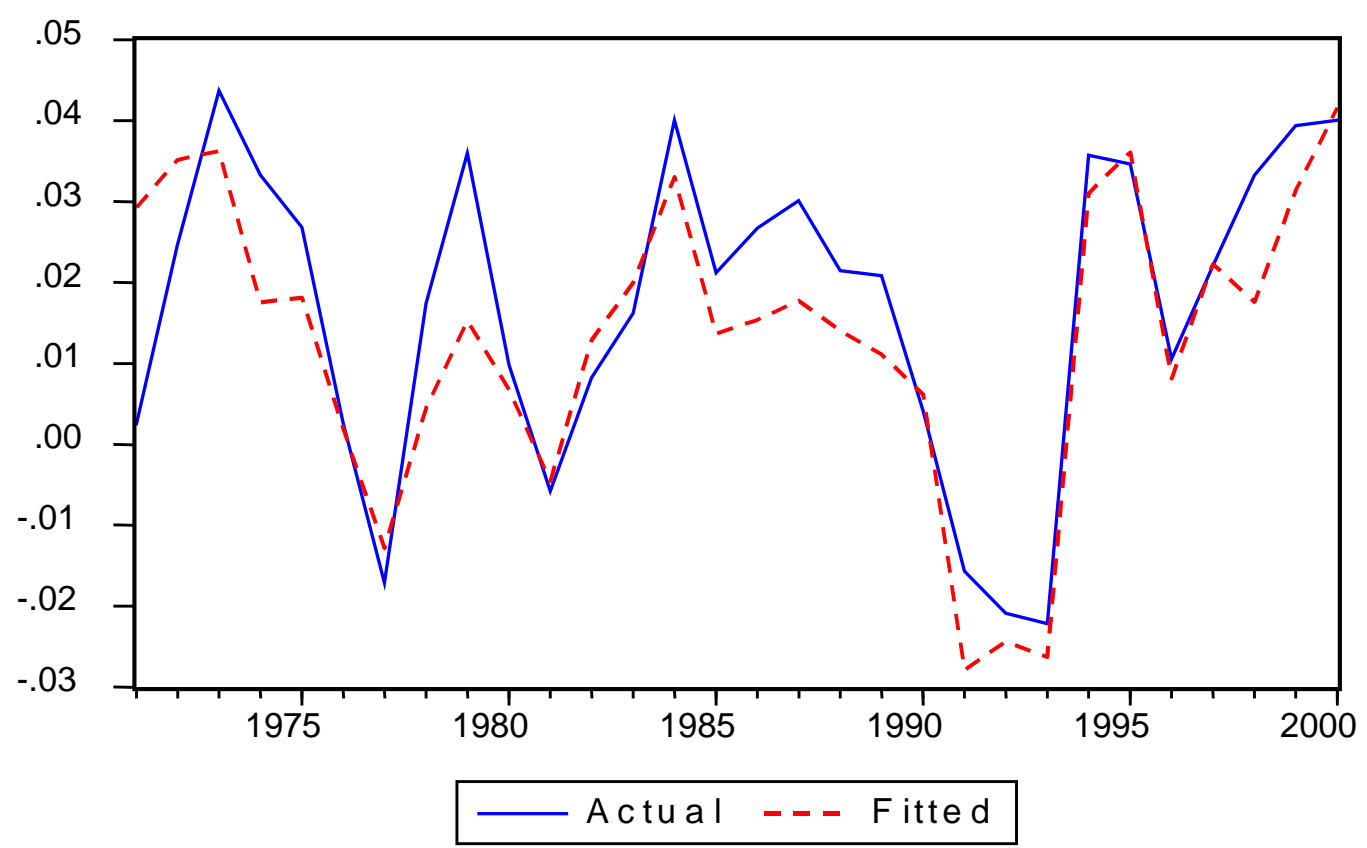

USA

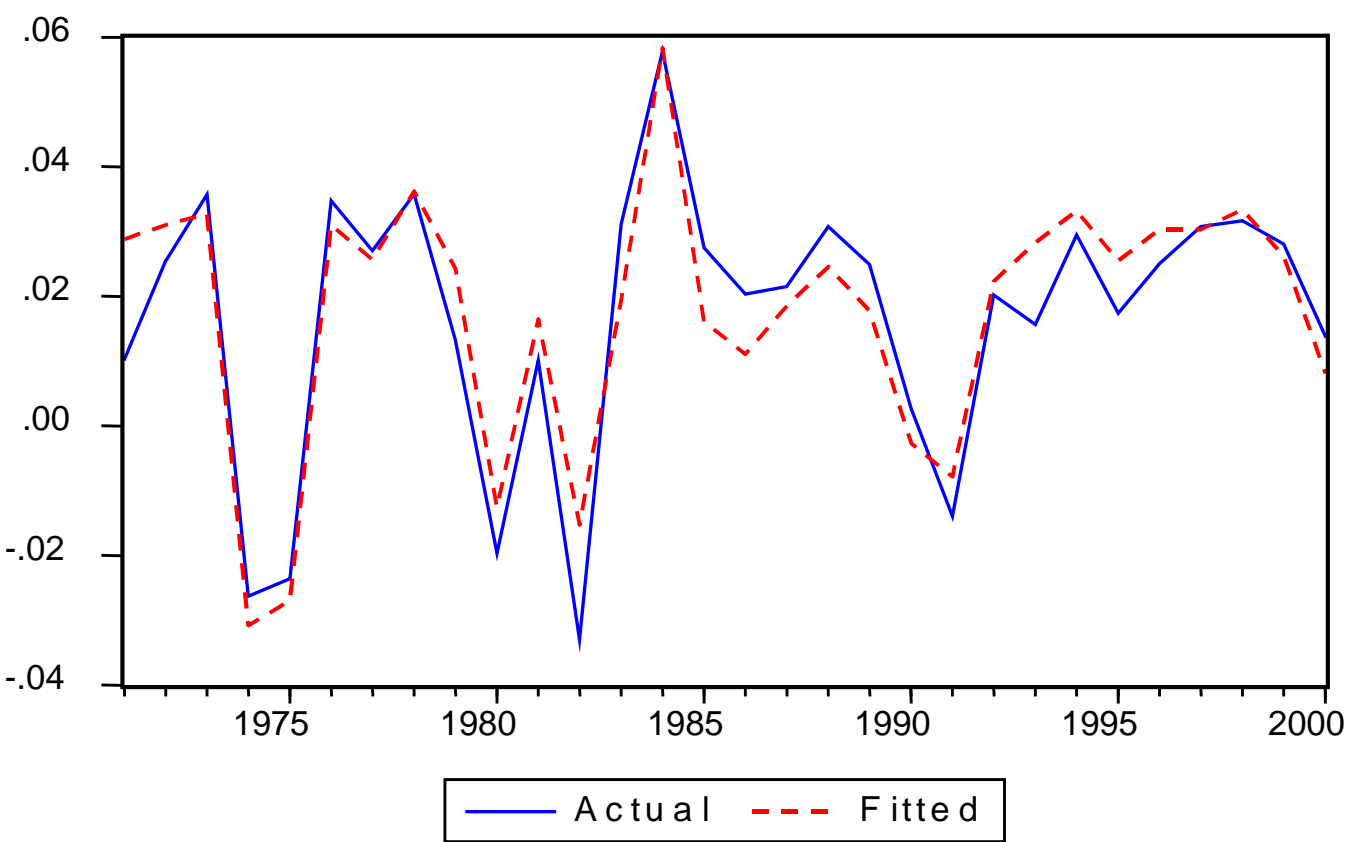


Table 4A: Summary statistics for actual growth of GDP per capita and the augmented growth model

\begin{tabular}{|c|c|c|c|c|c|c|}
\hline \multirow[b]{2}{*}{ Country } & \multicolumn{2}{|c|}{$\begin{array}{l}\text { Actual growth of } \\
\text { GDP per capita }\end{array}$} & \multicolumn{2}{|c|}{ Fitted model } & \multicolumn{2}{|c|}{$\begin{array}{l}\text { Fitted model exclud. } \\
\text { short-run dynamics }\end{array}$} \\
\hline & Mean & Std. Dev. & Mean & Std. Dev. & Mean & Std. Dev. \\
\hline Austria & $1.96 \%$ & $1.68 \%$ & $1.25 \%$ & $1.38 \%$ & $1.18 \%$ & $0.80 \%$ \\
\hline Belgium & $2.03 \%$ & $1.83 \%$ & $1.46 \%$ & $1.67 \%$ & $0.92 \%$ & $1.06 \%$ \\
\hline Germany & $1.31 \%$ & $2.58 \%$ & $1.22 \%$ & $8.53 \%$ & $1.54 \%$ & $8.00 \%$ \\
\hline Denmark & $1.65 \%$ & $1.92 \%$ & $1.42 \%$ & $1.69 \%$ & $1.61 \%$ & $0.61 \%$ \\
\hline France & $1.71 \%$ & $1.46 \%$ & $1.35 \%$ & $1.31 \%$ & $1.45 \%$ & $0.71 \%$ \\
\hline United Kingdom & $1.95 \%$ & $2.18 \%$ & $1.54 \%$ & $2.09 \%$ & $1.33 \%$ & $1.07 \%$ \\
\hline Italy & $1.99 \%$ & $1.93 \%$ & $1.83 \%$ & $1.76 \%$ & $1.35 \%$ & $0.83 \%$ \\
\hline Japan & $2.47 \%$ & $1.93 \%$ & $0.59 \%$ & $1.86 \%$ & $0.51 \%$ & $1.33 \%$ \\
\hline Netherlands & $1.68 \%$ & $1.72 \%$ & $0.56 \%$ & $1.70 \%$ & $0.45 \%$ & $1.61 \%$ \\
\hline Norway & $2.85 \%$ & $1.73 \%$ & $2.49 \%$ & $1.39 \%$ & $2.45 \%$ & $1.05 \%$ \\
\hline Sweden & $1.76 \%$ & $1.97 \%$ & $1.20 \%$ & $1.83 \%$ & $1.19 \%$ & $0.97 \%$ \\
\hline USA & $1.68 \%$ & $2.17 \%$ & $1.69 \%$ & $2.03 \%$ & $0.73 \%$ & $0.40 \%$ \\
\hline
\end{tabular}

